\title{
Does Herding Bias Drive the Firm Value? Evidence from the Chinese Equity Market
}

\author{
Sayyed Sadaqat Hussain Shah ${ }^{1} \mathbb{1}$, Muhammad Asif Khan ${ }^{2,3, *} \mathbb{0}$, Natanya Meyer ${ }^{4}(\mathbb{D}$, \\ Daniel F. Meyer ${ }^{5}$ and Judit Oláh ${ }^{6}$ (i)
}

1 Department of Commerce and Finance, Faculty of Arts and Social Sciences, Government College University Lahore, Lahore 54000, Pakistan; shah.sadaqat@gmail.com

2 School of Economics and Management, Yanshan University, 438, Hebei Avenue, Qinhuangdao City 066004, China

3 Department of Commerce, Faculty of Management Sciences, University of Kotli, Village Kurti, City Kotli, Azad Jammu and Kashmir 11100, Pakistan

4 WorkWell Research Unit, North-West University, Faculty of Economic and Management Sciences, School of Management, Vanderbijlpark 1900, South Africa; Natanya.Meyer@nwu.ac.za

5 TRADE Research Entity, North-West University, Faculty of Economic and Management Sciences, Vanderbijlpark 1900, South Africa; Daniel.Meyer@nwu.ac.za

6 University of Debrecen, Faculty of Economics and Business, Institute of Applied Informatics and Logistics, 4032 Debrecen, Hungary; olah.judit@econ.unideb.hu

* Correspondence: khanasif82@hotmail.com

Received: 29 August 2019; Accepted: 27 September 2019; Published: 10 October 2019

check for updates

\begin{abstract}
Equity markets play a pivotal role in the sustainability of developing countries, such as China. The literature on the detection of herding biases is confined to the aggregate level (firms, sector/industry and market). The present study adds to the behavioral finance literature by addressing the surprisingly unnoticed phenomena of the behavioral impact of herding bias on firm value (FV) at the firm level, using the sample of A-Shares listed firms at the Shanghai and Shenzhen Stock Exchanges (SSE and SZSE) under panel fixed effect specification. Initially, we detect the existence of investors and managers herding (IHR and MHR) biases at firm-level, and later, we examine their impact (distinct and interactive) upon the FV. The empirical results document the presence of IHR and MHR bias at market, sector and firm-level in both equity markets, which potentially drive the FV, while the impact is more pronounced during the extreme trading period. The findings are robust under different time intervals, and industry classification, therefore, offers useful policy implications to understand the behavioral dynamics of investors and managers.
\end{abstract}

Keywords: Investor herding bias; manager herding bias; firm value; Shanghai stock exchange; Shenzhen stock exchange

\section{Introduction}

The stock market trading dilemma is the cumulative reflections of investors' behavior [1]. Investors exhibit behavioral irregularities (biases) which potentially influence market efficiency [2,3]. Among these biases, herding bias is the most prominent, which is associated with the trading behavior of financial markets' participants [4,5]. It has become a subject of widespread interest in the recent decade [6-8]. Herding refers to the situation wherein rational people start behaving irrationally by imitating the judgments of others while making decisions [3]. Herding theories posit that market participants prefer to follow the financial experts in their trading patterns instead of their own source of information [9].The study of [10] believes that the herding of investors is one of the major risk factors that is typically ignored by statistical approaches. 
In the past decade, the study of herding documents this diverse behavioral pattern across the globe. In the context of the U.S. markets, Christie and Huang [5] report the absence of herding bias, even during extreme market movements. Conversely, Choi and Sias [11] point out the presence of a strong institutional industry herding bias. Likewise, Wang and Zhang [12] investigate the impact of individual investor trading on the firm value (FV) at the New York Stock Exchange (NYSE), and find the positive impact of investor trading on FV. European evidence [13] illustrates the presence of herding bias in the "during crises" period. Also, Walter and Moritz Weber [14] identify the herding bias of mutual fund managers in Germany during extreme market movements. Chinese, Taiwanese and South Korean stock markets also reveal herding behavior [15-18]. In the Chinese equity market, Demirer and Kutan [19] empirically analyze the behavior of return dispersions during periods of unusually large upward and downward changes in the market index of both the SSE and SZSE, and conclude that the Chinese Market is free from herding bias, and a similar approach is used by Demirer et al. [20]. Conversely, Tan et al. [21] explore the evidence of herding bias at the SSE and the SZSE, the A-share and B-share markets. They also report the existence of herding bias in both rising and falling market conditions, specifically more pronounced in the A-shares of the Shanghai Market during rising market conditions. Bo et al. [22] witness the investment herding bias among the corporate board, directors, and CEOs of non-financial firms from 1999 to 2004, and the consequent positive and significant impact on the FV. Similarly, another group of studies [23-25] report the mixed results of herding bias at the SSE and SZSE.

The above-mentioned studies highlight herding bias in two ways: First, the evidence of investors herding at market, industry/sector and firm-level during the extreme market conditions [17,19]; Second, the evidence of an investment-herding bias of the corporate manager [14] and their impact on the FV [22]. For the best of our knowledge, there is not a single study which explains the individual and interactive impact of investor and manager herding (IHR and MHR) biases on the FV. So, motivated by the recent studies $[6,12,22]$ that manager and investor demonstrate herding bias in their investment decision, this study empirically investigates the following questions:

1. Whether the investor herding bias exists at market-, sectors- and firm-level Chinese equity markets?

2. Do managers of the firm also exhibit herding bias in Chinese equity markets?

3. What is the individual and interactive impact of investors' and managers' herding bias on the FV?

The Chinese Financial Equity Market is important to be analyzed as it has an influence on integrated markets [26], while in China there is a need to strengthen the financial resources for sustainable development and poverty reduction [27]. Based on the literature and the questions stated above, this study adds to the existing literature in the following ways: Firstly, it hypothesizes the presence of herding bias in the Chinese equity markets at the market and industry/sector level, in line with $[8,15,19,28]$, and later it extends the phenomena at the firm level, which is a unique addition to the behavioral finance literature. Importantly, the market and sector level herding is insufficient to explain the investor's behavior associated to the firm, as Demirer and Zhang [17] find that the firm characteristics, their size and the past return has a significant effect on the herding behavior of the investor. Secondly, to the best of our knowledge, this is the first study that examines the impact of IHR and MHR on the FV. Finally, another most interesting contribution is in the form of the interactive impact of both IHR and MHR on the FV, which provides insights into understanding how both stakeholders jointly influence the FV.

Overall results demonstrate that: (i) Herding behavior exists at market-, sector- and firm-level at the SSE and SZSE, and a non-linear and significant relationship exists between stock return and cross-sectional absolute deviation (CSAD), which seems to be more pronounced in herding bias at all levels at the SZSE. The CSAD model explains 95\% and 99\% herding bias at the market level, $26 \%$ and $32 \%$ at sectors level, and $10 \%$ and $12 \%$ at the firm level at SSE and SZSE, respectively. While an absolute investment deviation model detects $51 \%$ and $54 \%$ of managers herding bias at SSE and SZSE, respectively. 
The empirical results also suggest that IHR and MHR affect the FV significantly during the extreme trading period (2014 to 2015), at both stock exchanges, while the interaction of IHR and MHR reveals the same at the SZSE in 2013. Importantly, the results are robust under different time intervals and industry classification.

The rest of this study is arranged as follows: Section 2 describes a brief literature and hypotheses development. Section 3 explains the methodological approach, including variable definitions, data sources and the sample period. Section 4 states the empirical results and discussion, while the final section concludes the study along with policy recommendations.

\section{Literature Review and Hypothesis Development}

Prior literature finds a diverse herding bias among participants in various stock markets. Empirical evidence on U.S. and Europeans investors and managers exhibits the presence of herding bias among mutual fund managers [29], analysts recommendation [30] and pension fund managers [31]. The aggregate effect of herding behavior is more prevalent in international markets, especially in emerging markets. Chang et al. [15] find significant evidence of herding bias in Taiwan and South Korea, alimited bias in Japan, and no bias in the U.S. and Hong Kong.

Later on, the Bueno [32] document herding bias in both theA-shares and B-shares of theChinese Stock Market. Furthermore, empirical analysis of herding on eighteen international markets by Chiang and Zheng [33] show the existence of herding in seven Asian and six advanced markets, whereas thenonexistence of herding behavior among both Latin American and U.S. markets, except during a crises period. Recent studies of Balcilar et al. [34] and Zheng et al. [35] also document herding behavior in the Gulf Arab and Asian markets. In Pakistan, the study of Javed et al. [36] and Javaira and Hassan [37] found no evidence of herding behavior in KSE 100 index companies at the Karachi Stock Exchange (KSE) for the period of 2002 to 2014. Whereas, the study of Yousaf et al. [38] on investor herding behavior in the Pakistan Stock Market during 2004 to 2014 reports the existence of herding behavior in the market, particularly in 2005 to 2008. Likewise, the empirical work of Shah et al. [28] for 2004 to 2013 also supports the significant evidence of herding behavior in this Pakistan Stock Market, specifically during the extreme market movements. Additionally, they found more than $50 \%$ of sectors at the PSX exhibit herding behavior during the upward market movements.

Demirer and Kutan [19] examine the presence of herd formation in Chinese markets using both individual firm and sector level data. They analyze the behavior of return dispersions during periods of unusually large upward and downward changes in the market index. They also distinguish sample data between the Shanghai and Shenzhen stock exchanges at the sector-level. Their findings show that herding bias does not exist in Chinese markets. However, comparing return dispersions for upside and downside movements of the market, these return dispersions during extreme downside movements of the market are much lower than those for upside movements, indicating that stock returns behave more similarly during down markets. Munkh-Ulzii et al. [39] find the presence of significant herding behavior in Chinese and Taiwan stock markets. Tan et al. [21] explore herding behavior in dual-listed Chinese A-share and B-share stocks. They find evidence of herding within both the Shanghai and Shenzhen A-share markets that are dominated by domestic individual investors, and also within both B-share markets, in which foreign institutional investors are the main participants.

Herding occurs in both rising and falling market conditions. Herding behavior by A-share investors in the Shanghai Market is more pronounced under conditions of rising markets, high trading volumeand high volatility, while no asymmetry is apparent in the B-share market. Lee et al. [24] document the effect of institutional herding on future stock returns in the China A-share Market at both the market and industry level from 2003 to 2012. Using a unique institutional holding database, they test the herding effect at different time horizons. The results suggest that institutional herding has a significantly positive effect on future excess returns for A shares in the short, medium and long periods of time. In the China A-share market, institutional herding is more significant on the buy-side than the sell-side due to short sell restrictions. 
At the industry level, manufacturing and construction sectors experience an institutional herding effect at all time horizons. The financial industry is found to present a significant institutional effect only in the long term.

The institutional herding has a positive and significant impact on the medium-term and long-term excess stock returns in the rest of ten sectors. Yao et al. [25] report the existence and prevalence of investor herding behavior in a segmented market setting, the Chinese A and B stock markets. The results indicate that investors exhibit different levels of herding behavior, in particular, herding strongly exists in the B-share markets. They also find that across markets, herding behavior is more prevalent at industry-level, is stronger for the largest and smallest stocks, and is stronger for growth stocks relative to value stocks. Herding behavior is also more pronounced under conditions of declining markets. Over the sample period which we are examining, herding behavior diminishes over time. The results provide some indication to the effectiveness of regulatory reforms in China aimed at improving information efficiency and market integration.

Lao and Singh [23] investigated herding behavior in the Chinese and Indian stock markets. Their results support that although both the Indian and Chinese stock markets are considered inefficient with low information disclosure standards, the Chinese Market exhibits herding behavior greater than the herding behavior in the Indian Market. Nevertheless, in both markets, herding behavior finds itself stronger in large market movements. Asymmetry investigation discovered that the Chinese Stock Market has the most profound herding behavior when the market is low and trading volume is high. Instead, in the Indian Market, herding behavior is observed when the market is high. In the Indian Market, herding behavior also had no association with trading volume. The reasons for herd behavior existing in the Chinese Stock Market, in both up and down states, are analyst forecast, short-term investor horizon, and inclusion of risk in decision making [40].

Although herding mentioned in the above studies contributesmuch to a better understanding of investor behavior at the SSE and SZSE, their aggregate results are confined at market and sector level, which also explains the mixed results, existence and nonexistence, of herding bias over time. Thus, consistent with the prior literature, we postulate the first hypothesis to test whether herding bias exists at the SSE and the SZSE during the sample period 2008 to 2017.

Hypothes (H1). Stock prices show significant herding behavior at the market and sector level.

Investors usually invest in those stocks with which they are familiar. Study of Huberman [41] considers the leading example of this phenomena. He explores the higher attention of employees in buying the security of those firms for which they work or are informed about from their peers. Ha [42] examined the impact of herding on the stock performance, and documentsthe very strong impact of herding on the stock returns and stock returns affect book to the market value of firms [43]. Also, Van Nieuwerburgh and Veldkamp [44] found the investors trending in home stock are much higher than the foreign stocks, while careful policy actions are needed to prevent malpractices [45]. Gebka and Wohar [46] document stronger irrationality behavior among the investors particularly in the Consumer Services, Oil and Gas and Basic Materials industries in the international equity markets. Following these examples, it can be figured that investors mostly invest in familiar stocks and industries preferably in the national stock market. Focusing on individual stock information for a specific industry may help to explore the herd behavior better rather than at the aggregate industry or market level. To address the answer to this question, we postulate the second hypothesis as below:

Hypothes (H2). Stock prices show significant herding behavior at the firm level in the Chinese stock market.

Detection of herding at any level is not enough to explain the behavior of investors toward the specific firm. Investors usually consider the FV while making their investment decision. The market value of stock reacts on the price momentum based upon the frequency of the investors' trade. Therefore, investors' trading patterns show many behavior irregularities and biases which affect the 
firm's performance. Among these biases, herding bias is the main behavioral bias [4], which significantly affects the firm's performance [6,8,22]. Wang and Zhang [12] elaborate on the positive impact of investor trading on the FV.

Also, Hilliard and Zhang [47] find the weaker size and price to book value effect on the herding behavior of the Chinese Stock Market relative to U.S. markets over the period of 1999 to 2012. Our study differs uniquely from the prior studies, and tries to capture the impact of the herding bias of investors, at the individual firm, on the FV listed as A-share at the SSE and SZSE. To examine such a relationship, we construct the following hypothesis.

Hypothes (H3). Ceteris paribus, IHR bias has a positive impact on the FV.H3: Ceteris paribus, IHR bias has a positive impact on the FV.

Effects of herding are not bounded to the investors only. Firms' managers also exhibit herding behavior in their financial decisions. Theories on herding behavior in standard literature assume that the information set upon which corporate managers are making investment decisions is truly perfect, and informative under a mature market system that guarantees a transparent corporate reporting system, mature laws and regulations, strong shareholders' protection and effective corporate governance mechanisms. Under such circumstances, the manager should make investment decisions based on the information set relevant to the firm. In contrast, Prendergast and Stole [48] discuss the herding intention of the managers who make investment decisions over time.Demirer and Zhang [17] find that small firms with a high level of herding significantly underperform from those small firms that experience low herding. They observe no significant interactions between book-to-market and market beta with herding. Chen and Demirer [8] point those industries that experience a high level of herding yield higher subsequent returns, regardless of their past performance.

Theories on herding find firms' managers usually follow their peers in investment decisions, instead of relying on their own source of information [9]. Garber [4] elaborates herding behavior as the most prominent bias in the psychology of judgment. In the recent past, the studies on manager investment herding behavior present the diverse behavioral pattern across the world. Fong et al. [49] demonstrate four general theories, classified into twoparts: Thefirst part belongs to intentional herding, and the second for unintentional herding. The authors state why managers may engage in herding behavior in their investment decisions as such: (1) Firm managers are subject to reputational risk when they behave differently from the crowd. Thus they may ignore private information to trade with the herd. (2) Managers may infer the private information of rival managers (perceived on their prior trades), resulting in the formation of informational cascades. (3) Managers may also receive similar private information because they also examine the same priced factors which caused them to arrive at similar conclusions regarding individual stocks. (4) Managers may exhibit similar aversions to stocks showing characteristics, such as low liquidity or low analyst coverage.

In the U.S. and European markets, herding behavior among managers of different industries is different. Choi and Sias [11] document strong institutional herding in U.S. corporations. Also, Walter and Moritz Weber [14] pinpoint the herding behavior of mutual fund managers in Germany. TheSouth Korea, Taiwanand China markets also exhibit herding behavior $[15,16]$. Many scholars examine the relationship between managerial career concerns and herding. Devenow and Welch [50] analytically illustrate herd behavior in making corporate investment decisions. In light of the above literature, we postulate hypothesis 4 :

Hypothes (H4). MHR bias has a positive impact on FV.

Firm financial performance is considered the most important indicator for investors and managers for the evaluation of their financial decisions. It has broad implications for investments, capital allocation and market efficiency of the business. Alabass [6] and Bo et al. [22] demonstrate a positive and significant impact of MHR bias on the FV. Theprevious two hypotheses, $\mathrm{H} 3$ and H4, are constructed to test the 
IHR and MHR bias individually. Perhaps it might be more logical to test the combined effect of herding bias to explore the magnitude of firm financial performance during the trading period. To investigate the combined effect of IHR and MHR bias on the FV, we test the following hypothesis:

Hypothes (H5). Interaction of the IHR and MHR has a positive influence on FV.

\section{Methodological Approach}

\subsection{Data Source and Study Period}

In this study, data are compiled from two data series of China Stock Market \& Accounting Research (CSMAR). Firstly, we collect stock-based data, e.g., closing price, trading volume for individual stocks, sector/industry indices and market indices from stock market series during the sample period of 2008 through 2017. Secondly, we collect firm-level data, e.g., market to book value (MB), cash flow (CF), firm leverage (FL), firm growth (FG) and firm size (FS) from the annual audited financial statement. Initially, we consider all the firms listed with Shanghai and Shenzhen Stock Exchanges (SSE and SZSE) during the stated period. Later the data constraint problem limits our sample to 664 and 379 from 41 and 67 sectors at the SSE and SZSE, respectively.

These sub-sections initially describe the detection mechanisms of investors herding (IHR) and managers herding (MHR) biases market, sector and firm-level, and later explain the fixed effect specification used to examine the impact of IHR and MHR on firm value (FV).

\subsection{Investors Herding}

Since there is no direct measure of herding in financial markets, in financial literature different proxies are used to capture it indirectly at different time spans. Accordingly, the herding behavior can be summarized in two ways. [17] first employs the asymmetric trading orders of buying and selling the security in the market, which shows herding behavior on the buying side or the selling side, e.g., if the buyer orders are more than the selling order, then it is identified as herd in buying, otherwise herd in selling. This strand of the literature explains herding behavior at the investors level [31]. Whereas, the later detects the herding behavior using a regression approach based on an asset-pricing model which links the cross-sectional deviation of security returns to the extreme movements of industry returns and market return. Usually, this approach captures herding behavior at the market/industry level. Mostly, the herding literature falls into the second approach (market and sector level), because in this way an appropriate sample of market participants can be analyzed at different time spans. This approach follows two common methodologies for herding bias. First is CSSD, and the second is Cross Sectional Absolute Deviation (CSAD). CSSD, initially proposed by Christie and Huang [5], calculates the cross-sectional deviation of stock returns as:

$$
\operatorname{CSSD}_{t}=\sqrt{\frac{\sum_{i=1}^{n}\left(r_{i, t}-r_{m, t}\right)^{2}}{n_{t}-1}}
$$

Where $n$ denotes the number of listed firms in the portfolio, $r_{i, t}$ is security i return at time $t$, and $r_{m, t}$ explains the equally-weighted returns of the portfolio at deviations. Christie and Huang [5] suggest that herding exists if the stock return dispersion by CSSD is significantly lower. Later on, Chang et al. [15] generalize the method for the herding behavior by adding the phenomena of CSAD, which is built on CAPM, for all market conditions. Our study is also based on the CSAD approach [15] for the detection of herd bias among the market participants, which is calculated as:

$$
\operatorname{CSAD}_{\mathrm{t}}=\frac{1}{\mathrm{~N}} \sum_{\mathrm{i}=1}^{\mathrm{N}}\left|\mathrm{R}_{\mathrm{i}, \mathrm{t}}-\mathrm{R}_{\mathrm{m}, \mathrm{t}}\right|
$$


Chang et al. [15] suggest that there should be a linear correlation of CSAD with the absolute value of the security. However, when herd bias occurs, investor trades follow the same market direction, and individual security returns tend to cluster around the overall market return. Thus, the linear relation turns to a nonlinear one.

Under the following situation, the negative and significant nonlinear relationship between CSAD and stock market return illustrates the presence of herding. Hence, the CSAD model for exploring herding behavior is constructed as follows:

$$
\operatorname{CSAD}_{\mathrm{m}, \mathrm{t}}=\alpha_{0}+\gamma_{1}\left|\mathrm{R}_{\mathrm{m}, \mathrm{t}}\right|+\gamma_{2} \mathrm{R}_{\mathrm{m}, \mathrm{t}}^{2}+\varepsilon_{\mathrm{t}}
$$

Where negative and significant $\gamma 2$ shows the presence of herding bias. As our study also focuses on industry level and firm-level herding, we transform the above model, as below:

$$
\begin{gathered}
\operatorname{CSAD}_{\text {Ind }, \mathrm{t}}=\frac{1}{\mathrm{~N}} \sum_{\mathrm{i}=1}^{\mathrm{N}}\left|\mathrm{R}_{\mathrm{i}, \mathrm{t}}-\mathrm{R}_{\text {ind }, \mathrm{t}}\right| \\
\mathrm{CSAD}_{\text {ind, } \mathrm{t}}=\alpha_{0}+\gamma_{1}\left|\mathrm{R}_{\text {ind_m, } \mathrm{t}}\right|+\gamma_{2} \mathrm{R}_{\text {ind_m, }}^{2}+\varepsilon_{t}
\end{gathered}
$$

In Equation (4), the $\mathrm{CSAD}_{\text {ind,t }}$ is calculated based on $\mathrm{N}$, the wholenumber of firms' security returns within the industry. For the calculation of $\mathrm{CSAD}_{\text {ind,t }}$, we use the average industry return $\left(R_{\text {ind, }}\right)$ for each of theindustry in the markets, along with the individual stock return $\left(R_{i, t}\right)$ listed in the same industry.

In Equation (5), $R_{\text {ind_m,t }}=R_{\text {ind, } t}-E\left(R_{\text {ind, }, t}\right)$, where $E\left(R_{\text {ind, }, t}\right)$ is the expected industry return which is based on CAPM, and calculated as $E\left(R_{\text {ind, }, t}\right)=\alpha+\beta R_{m, t}$.

$$
\begin{gathered}
\operatorname{CSAD}_{\text {firm, } t}=\frac{1}{n} \sum_{i}^{n}\left|R_{i, t}-R_{\text {ind, } t}\right| \\
\operatorname{CSAD}_{\text {firm, } t}=\alpha_{0}+\gamma_{1}\left|R_{\text {firm_ind, }, t}\right|+\gamma_{2} R_{\text {firm_ind }}^{2}+\varepsilon_{t}
\end{gathered}
$$

In Equation (6), we extend the model and calculate $\mathrm{CSAD}_{\text {firm_ind,t }}$ of all firms' security returns within the sectors, based on n numbers of observations. Moreover, in Equation (7), we replace return of firm in the industry at time $t$ instead of the return of industry at time $t$ in the Equation (5), where $R_{\text {firm_ind, } t}=R_{\text {firm_ind, } t}-E\left(R_{\text {firm_ind, } t}\right)$, as expected firm return in the sector based on $E\left(R_{\text {firm_ind, } t}\right)=$ $\alpha+\beta_{\text {Rind, } t}$. We calculate stock returns of market, industry and firm as $\mathrm{R}=\log \left(\mathrm{P}_{\mathrm{t}} / \mathrm{P}_{\mathrm{t}-1}\right)$, where Pt denotes the recent price of stock and $\mathrm{P}_{\mathrm{t}-1}$ is the last price of the stock. For consideration of handling the outliers, we trim the return data at the $99^{\text {th }}$ percentile. The specification of this model is consistent with [25]. On the basis of $\gamma 2$ of the $\left(\mathrm{CSAD}_{\text {firm_ind,t }}\right)$ model, we construct our index investor herding bias (IHR) of each firm from each sector and assign dummy values 1 , if $\gamma 2$ of $\left(\mathrm{CSAD}_{\text {firm_ind,t }}\right)$ model is negative and significant and 0 otherwise.

\subsection{Managers Herding}

We use an absolute investment deviation ratio model as a proxy of MHR bias as suggested by Alabass [6] andBo et al. [22]. In the investment ratio model, herding exists if managers of firm i follow the investment decisions of their peers. In normal practice, it is impossible to consider that managers observe the contemporaneous investment decisions of other firms while making their own investment decisions. Perhapsit is more logical to presume that firms' managers are aware of the average investment value of other firms, listed in the same industry, in recent years. Managers often 
consider the last year industry average investment value as a reference for their investment decisions, therefore, the proxy for investment herding is defined as:

$$
\mathrm{MHR}_{\mathrm{t}}=|| \frac{\mathrm{I}}{\mathrm{K}_{\mathrm{i}, \mathrm{t}}}|-| \overline{\frac{\mathrm{I}}{\mathrm{K}}-\mathrm{i}, \mathrm{t}-1}||
$$

Which is the absolute deviation of the investment ratios; the ratio of investment to the capital stock of firm $i$ at the time $t$, and the average investment ratio of other firms in the same sectors, excluding firm $i$ at time year $(\mathrm{t}-1)$. While computing the investment ratio $(\mathrm{I} / \mathrm{K})_{\mathrm{i}, \mathrm{t}}$, we first sort the data by sectors, followed by sorting within sectors for the measurement of the average investment ratio $(\overline{I / K})_{-\mathrm{i}, \mathrm{t}-1}$ of other firms in the same sectors. Following Bo et al. [22] we also calculate net investment I, such as the net changes in fixed assets (FA) of the firm i.e., ( $\mathrm{I}=\Delta \mathrm{FA})$ and capital stock at the beginning of the period, $\mathrm{K}_{\mathrm{i}, \mathrm{t}}$ by the total assets (TA) of a firm. A smaller investment deviation suggests herding, the managers of firm $i$ make a similar investment decision to the other firms listed in the same industry. Therefore, based on a smaller investment deviation of the model as a proxy of manager herding, we construct a new index for MHR, and assign adummy value of 1 if herding exists, otherwise 0 .

\subsection{Herding and Firm Value}

To examine the effect of IHR, MHR on FV, the theoretical association between these variables can functionally be expressed as:

$$
\mathrm{FV}_{\mathrm{t}}=\mathrm{f}\left(\mathrm{IHR}_{\mathrm{t}}, \mathrm{MHR}_{\mathrm{t}}, \mathrm{CF}_{\mathrm{t}}, \mathrm{FL}_{\mathrm{t}}, \mathrm{FS}_{\mathrm{t}}, \mathrm{FG}_{\mathrm{t}}\right)
$$

We transformed Equation (1) into mathematical expression:

$$
\mathrm{FV}_{\mathrm{t}}=\beta_{0}+\beta_{1} \mathrm{IHR}_{\mathrm{t}}+\beta_{2} \mathrm{MHR}_{\mathrm{t}}+\beta_{3} \mathrm{CF}_{\mathrm{t}}+\beta_{4} \mathrm{FL}_{\mathrm{t}}+\beta_{5} \mathrm{FS}_{\mathrm{t}}+\beta_{6} \mathrm{FG}_{\mathrm{t}}+\gamma+\mu+\epsilon
$$

In the above Equation, $\mathrm{FV}_{\mathrm{t}}$ denotes $\mathrm{FV}$ as the dependent variable, and is measured by the market to book value (MB) [22,51-53]. $\mathrm{IHR}_{\mathrm{t}}$ and $\mathrm{MHR}_{\mathrm{t}}$ show investors and managers herding as independent variables, and this is measured by the methodologies of Chang et al. [15], and Bo et al. [22]. Whereas, $\mathrm{CF}_{t}$ for cash flow to assets, $\mathrm{FL}_{t}$ for firm leverage, $\mathrm{FS}_{t}$ for firm size and $\mathrm{FG}_{t}$ are control variables as suggested by bothChen and Lin [54] and Bo et al. [22]. $\gamma$ and $\mu$ are used for industry and years fixed effects, whereas $\epsilon$ explains the error terms of the model. Table 1 presents the detailed information of all variables.

Table 1. Explanation of Variables.

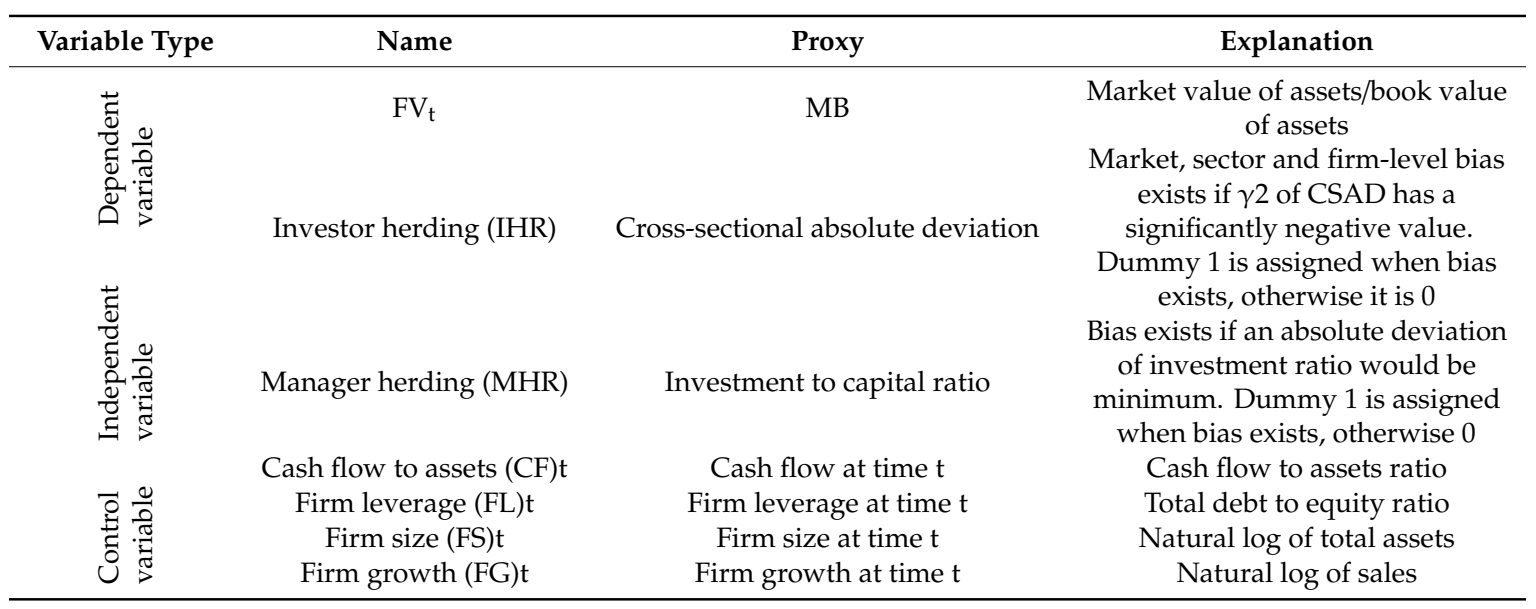

Source: Authors' own research, 2019. 


\section{Empirical Results and Discussion}

Table 2 presents the descriptive analysis of the firm's financial data at the SSE and SZSE for the period of 2008 to 2017, in terms of mean, minimum and maximum values, and standard deviation of the FV, Tobin's Q-Ahmad et al. [55] and control variables such as cash flow (CF), firm leverage (FL), firm size (FS), and firm growth (FG). Column (1) and (6) report the mean values of FV, i.e., 1.88 and 2.136 with the standard deviation of 1.92 and 1.94, and the minimum to maximum range, 0.188 to 11.967 and 0 to 0.49 , at the SSE and SZSE, respectively. While the rest of the columns explain the description of the control variables, where FS has a relatively higher mean value with lower deviation, and CF has a relatively least average value with least deviation among the firms of two stock exchanges.

Table 2. Descriptive Statistics at the Shanghai and Shenzhen Stock Exchanges (SSE and SZSE) (2008-2017).

\begin{tabular}{|c|c|c|c|c|c|c|c|c|c|c|}
\hline \multirow{3}{*}{ Variable } & \multicolumn{5}{|c|}{ SSE } & \multicolumn{5}{|c|}{ SZSE } \\
\hline & (1) & (2) & (3) & (4) & (5) & (6) & (7) & (8) & (9) & (10) \\
\hline & FV & $\mathrm{CF}$ & FL & FS & FG & FV & $\mathrm{CF}$ & FL & FS & FG \\
\hline Mean & 1.88 & 0.099 & 1.586 & 22.28 & 0.971 & 2.136 & 0.1 & 1.319 & 21.94 & 0.841 \\
\hline Std.Dev. & 1.926 & 0.099 & 1.776 & 1.365 & 0.645 & 1.949 & 0.1 & 1.492 & 1.269 & 0.594 \\
\hline Min & 0.188 & 0 & -1.953 & 19.22 & 0.246 & 0.188 & 0 & -1.953 & 19.22 & 0.246 \\
\hline Max & 11.967 & 0.49 & 10.845 & 25.88 & 2.203 & 11.967 & 0.49 & 10.85 & 25.88 & 2.203 \\
\hline Obs & 6640 & 6640 & 6640 & 6640 & 6640 & 3790 & 3790 & 3790 & 3790 & 3790 \\
\hline
\end{tabular}

Source: Authors' own research, 2019.

The pairwise correlation results of Table 3 haveno evidence of multicollinearityamong variables of SSE and SZSE for the period of 2008 to 2017. All variables are significantly related to each other, except the CF in SZSE, which has a positive and insignificant relation with FG.

Table 3. Correlation matrix at SSE and SZSE (2008-2017).

\begin{tabular}{cccccc}
\hline Variables SSE/SZE & FV & CF & FL & FS & FG \\
\hline FV & 1 & $0.131^{*}$ & $-0.162 *$ & $-0.490^{*}$ & $-0.335^{*}$ \\
CF & $0.050^{*}$ & 1 & $-0.138^{*}$ & $-0.033^{*}$ & 0.004 \\
FL & $-0.130^{*}$ & $-0.128^{*}$ & 1 & $0.191^{*}$ & $0.159 *$ \\
FS & $-0.528^{*}$ & $-0.025^{*}$ & $0.145^{*}$ & 1 & $0.678 *$ \\
FG & $-0.392^{*}$ & $0.043^{*}$ & $0.138^{*}$ & $0.707^{*}$ & 1 \\
\hline
\end{tabular}

Note: * shows significance at the 0.05 level. The lower part of principal diagonal "1" explains correlation matrix for SSE and upper part present matrix for SZSE.Source: Authors' own research, 2019.

\subsection{Herding at Equity Markets}

This section presents the empirical results of herding bias at a market level between two stock markets, i.e., the SSE and the SZSE by using the CSAD model $[15,28]$. Therefore, a negative and significant $\gamma_{2}$ (CSAD model coefficient) exhibits evidence of herding behavior.

Table 4 exhibits the evidence of herding behavior by CSAD model in A-shares of SSE and SZSE during the sample period starting from 2008 to 2017. In Table 4, negative and significant $\gamma_{2}$ with coefficients (-1.146) and (-1.741), and $t$-values $(-2.08)$ and (-4.49), present the evidence of a herding bias in the SSE and SZSE, respectively, during the said sample period. Furthermore, this herding bias is seeming more prevalent in the A- Shares of SZSE, at a 99\% level of confidence, which are consistent with the literature $[16,19]$. 
Table 4. Level A-Share Herding Bias at SSE and SZSE (2008-2017).

\begin{tabular}{ccccc}
\hline CSAD $_{\mathrm{m}, \mathrm{t}}$ & $\mathbf{A}$ & $\gamma_{1}$ & $\gamma_{2}$ & Adjusted $^{2}$ \\
\hline \multirow{2}{*}{$\mathrm{SSE}$} & $0.013^{* * *}$ & $0.197^{* * *}$ & $-1.146^{* *}$ & 0.037 \\
& $(24.3)$ & $(4.94)$ & $(-2.08)$ & \\
SZSE & $0.013^{* * *}$ & $0.209^{* * *}$ & $-1.741^{* * *}$ & 0.067 \\
& $(27.74)$ & $(7.27)$ & $(-4.49)$ & \\
\hline
\end{tabular}

Source: Authors' own research, 2019; Note: ${ }^{* * * * * * *}$ denote test statistics significant at $10 \%, 5 \%$, and $1 \%$ respectively, while $\mathrm{t}$-value in parenthesis.

\subsection{IHR Bias at Industry/Sector Level}

Tables 5 and 6 incorporate the evidence of industry/sector level herding bias by CSAD model (5) in the A-shares of the SSE and SZSE. The results in Table 5 indicate herding bias among 11 sectors out of 41-these sectors are agriculture, food manufacturing, leather, fur, feathers and footwear production, petroleum processing, coking and nuclear fuel processing, metal products industry, housing construction, warehousing industry, other financial industry, health and comprehensive industry $\left(\gamma_{2}\right.$ is negative and significant). Table 6 attributes investors' herding bias among 22 sectors out of 67 at the SZSE. These sectors include animal husbandry, forestry and fishery services, the agricultural and food processing industries, food manufacturing, the wood processing industry, culture and entertainment products manufacturing, the rubber and plastic products industry, non-ferrous metal smelting and rolling processing industry, instrumentation manufacturing, handling and transportation agency, internet and related services, ecological protection and environmental management, news and publishing, comprehensive, the wholesale industry, retail industry, air transport industry, catering, monetary financial services, the real estate industry, and media operations. While, 30/41 and 45/67 sectors at SSE and SZSE, respectively, are free from the herding, $\gamma_{2}\left(\operatorname{CSAD}_{\text {int, }}\right.$ model, coefficient) is negative/positive and insignificant. Our findings are supported by prior literature $[16,19,28]$.

Table 5. Industry Herding Bias at the SSE (2008-2017).

\begin{tabular}{|c|c|c|c|c|c|c|c|c|}
\hline Sectors & Name & A & t-stat & $\gamma_{1}$ & t-stat & $\gamma_{2}$ & t-stat & Adjusted $R^{2}$ \\
\hline 1 & A01 & $0.010^{* * *}$ & (19.21) & $0.346^{* * *}$ & $(9.27)$ & $-2.649 * * *$ & $(-5.49)$ & 0.065 \\
\hline 2 & A02 & $0.007^{* * *}$ & (21.76) & $0.088^{* * *}$ & (7.99) & -0.050 & $(-1.49)$ & 0.055 \\
\hline 3 & A03 & $0.008^{* * *}$ & (22.29) & $-0.125^{* * *}$ & $(-7.65)$ & $2.662 * * *$ & (20.98) & 0.232 \\
\hline 4 & A04 & $0.011^{* * *}$ & (29.95) & $-0.036^{* *}$ & $(-2.24)$ & $-2.273^{* * *}$ & (18.44) & 0.244 \\
\hline 5 & A05 & $0.009^{* * *}$ & (16.27) & -0.015 & $(-0.60)$ & $3.234^{* * *}$ & (20.85) & 0.316 \\
\hline 6 & B07 & $0.010^{* * *}$ & (21.21) & $0.119^{* * *}$ & (3.95) & $2.223^{* * *}$ & $(6.23)$ & 0.164 \\
\hline 7 & B08 & $0.012 * * *$ & (19.94) & 0.019 & $(0.51)$ & $2.340 * * *$ & $(5.26)$ & 0.081 \\
\hline 8 & B09 & $0.013^{* * *}$ & $(44.92)$ & $0.061^{* * *}$ & $(4.71)$ & $2.484^{* * *}$ & (62.95) & 0.756 \\
\hline 9 & B11 & $0.010^{* * *}$ & (22.72) & 0.026 & (1.46) & $2.120^{* * *}$ & (26.37) & 0.409 \\
\hline 10 & $\mathrm{C} 13$ & $0.014^{* * *}$ & (25.88) & -0.012 & $(-0.33)$ & $2.808^{* * *}$ & $(6.56)$ & 0.096 \\
\hline 11 & $\mathrm{C} 14$ & $0.013^{* * *}$ & (28.46) & $0.128^{* * *}$ & $(8.73)$ & $-0.067^{* * *}$ & $(-6.36)$ & 0.072 \\
\hline 12 & C15 & $0.014^{* * *}$ & (58.48) & $0.078^{* * *}$ & (7.86) & $1.798^{* * *}$ & (77.08) & 0.839 \\
\hline 13 & C18 & $0.016^{* * *}$ & $(49.71)$ & $-0.265^{* * *}$ & $(-18.02)$ & $6.179^{* * *}$ & (57.24) & 0.636 \\
\hline 14 & C19 & $0.006^{* * *}$ & $(6.60)$ & $0.415^{* * *}$ & $(7.01)$ & $-4.284 * * *$ & $(-6.56)$ & 0.158 \\
\hline 15 & $\mathrm{C} 20$ & $0.007^{* * *}$ & $(5.48)$ & $0.329 * * *$ & $(3.44)$ & -2.354 & $(-1.37)$ & 0.216 \\
\hline 16 & C21 & $0.011^{* * *}$ & $(9.92)$ & 0.033 & $(0.53)$ & $6.484^{* * *}$ & (18.51) & 0.835 \\
\hline 17 & $\mathrm{C} 22$ & $0.013^{* * *}$ & (10.43) & -0.144 & $(-1.19)$ & $16.392^{* * *}$ & $(6.88)$ & 0.425 \\
\hline 18 & $\mathrm{C} 23$ & $0.007^{* * *}$ & $(7.91)$ & $0.146^{*}$ & $(1.81)$ & 0.752 & $(0.41)$ & 0.197 \\
\hline 19 & $\mathrm{C} 24$ & $0.008^{* * *}$ & (10.51) & $0.463^{* * *}$ & (6.83) & $5.617^{* * *}$ & (16.35) & 0.933 \\
\hline 20 & $\mathrm{C} 25$ & -0.002 & $(-0.47)$ & $1.138^{* * *}$ & (3.50) & $-12.514^{* * *}$ & $(-3.01)$ & 0.389 \\
\hline 21 & $\mathrm{C} 28$ & $0.006^{* * *}$ & $(6.75)$ & $0.309 * * *$ & (3.08) & 0.328 & $(0.12)$ & 0.270 \\
\hline 22 & $\mathrm{C} 29$ & $0.008^{* * *}$ & $(9.11)$ & -0.006 & $(-0.05)$ & $24.212^{* * *}$ & $(5.16)$ & 0.412 \\
\hline 23 & C32 & $0.009^{* * *}$ & $(8.78)$ & $0.293^{* * *}$ & $(3.66)$ & 1.232 & $(0.68)$ & 0.306 \\
\hline 24 & C33 & $0.007^{* * *}$ & $(9.34)$ & 0.101 & (1.25) & $-6.916^{* * *}$ & $(2.89)$ & 0.349 \\
\hline 25 & C38 & $0.006^{* * *}$ & $(6.92)$ & $0.201 * *$ & $(2.52)$ & 2.854 & (1.63) & 0.370 \\
\hline
\end{tabular}


Table 5. Cont.

\begin{tabular}{llllccccc}
\hline 26 & C40 & $0.011^{* * *}$ & $(13.11)$ & 0.085 & $(1.22)$ & $7.396^{* * *}$ & $(4.02)$ & 0.429 \\
27 & E47 & $0.012^{* * *}$ & $(7.46)$ & -0.062 & $(-0.44)$ & $-10.440^{* * *}$ & $(4.64)$ & 0.311 \\
28 & G53 & $0.008^{* * *}$ & $(6.80)$ & 0.198 & $(1.55)$ & 3.351 & $(0.94)$ & 0.177 \\
29 & G58 & $0.006^{* * *}$ & $(6.56)$ & $0.350^{* * *}$ & $(2.84)$ & 4.851 & $(1.55)$ & 0.293 \\
30 & G59 & $0.005^{* * *}$ & $(5.61)$ & 0.140 & $(1.39)$ & $-5.289^{* *}$ & $(2.53)$ & 0.292 \\
31 & I63 & $0.100^{* *}$ & $(6.25)$ & -1.182 & $(-1.73)$ & 1.770 & $(0.25)$ & 0.999 \\
32 & I64 & $0.011^{* * *}$ & $(7.28)$ & -0.187 & $(-1.38)$ & $9.974^{* * *}$ & $(5.95)$ & 0.406 \\
33 & $\mathrm{~J} 66$ & $0.008^{* * *}$ & $(5.05)$ & $0.336^{* * *}$ & $(3.02)$ & -1.149 & $(-0.76)$ & 0.175 \\
34 & $\mathrm{~J} 68$ & $0.009^{* * *}$ & $(7.55)$ & $0.374^{* * *}$ & $(3.95)$ & -0.938 & $(-0.74)$ & 0.217 \\
35 & $\mathrm{~J} 69$ & $0.003^{* * *}$ & $(4.32)$ & $0.310^{* * *}$ & $(5.30)$ & $-3.294^{* * *}$ & $(-4.54)$ & 0.118 \\
36 & M74 & $0.010^{* * *}$ & $(8.93)$ & $-0.126^{* * *}$ & $(-2.71)$ & $3.313^{* * *}$ & $(17.83)$ & 0.779 \\
37 & $\mathrm{~N} 77$ & $0.006^{* * *}$ & $(5.75)$ & $0.139^{* *}$ & $(2.01)$ & -0.364 & $(-0.35)$ & 0.072 \\
38 & $\mathrm{Q} 83$ & $0.009^{* * *}$ & $(4.58)$ & $0.487^{* * *}$ & $(4.53)$ & $-5.222^{* * * *}$ & $(-4.11)$ & 0.172 \\
39 & $\mathrm{R} 85$ & $0.007^{* * *}$ & $(5.03)$ & $0.358^{* * *}$ & $(3.51)$ & -3.016 & $(-1.50)$ & 0.174 \\
40 & $\mathrm{R} 86$ & $0.009^{* * *}$ & $(7.15)$ & 0.073 & $(0.89)$ & 0.153 & $(0.13)$ & 0.062 \\
41 & $\mathrm{~S} 90$ & $0.007^{* * *}$ & $(15.05)$ & $0.406^{* * *}$ & $(14.59)$ & $-3.765^{* * *}$ & $(-11.00)$ & 0.140 \\
\hline
\end{tabular}

Note: ${ }^{*}, * * * *$ denote test statistics significant at $10 \%, 5 \%$, and $1 \%$ respectively, while $p$-value in parenthesis.

Table 6. Industry Herding Bias at the SZSE (2008-2017).

\begin{tabular}{|c|c|c|c|c|c|c|c|c|}
\hline Sectors & Codes & $\alpha$ & t-stat & $\gamma_{1}$ & t-stat & $\gamma_{2}$ & t-stat & Adjusted $\mathrm{R}^{2}$ \\
\hline 1 & A01 & $0.013^{* * *}$ & (21.15) & -0.017 & $(-0.44)$ & $3.557 * * *$ & $(8.00)$ & 0.120 \\
\hline 2 & A02 & $0.013^{* * *}$ & (28.11) & $-0.169^{* * *}$ & $(-7.39)$ & $5.350 * * *$ & (26.80) & 0.374 \\
\hline 3 & A03 & $0.014^{* * *}$ & (24.27) & $-0.194^{* * *}$ & $(-5.47)$ & $-6.004^{* * *}$ & (14.77) & 0.194 \\
\hline 4 & A03 & $0.015^{* * *}$ & (25.95) & $-0.165^{* * *}$ & $(-5.66)$ & $5.456^{* * *}$ & (23.82) & 0.289 \\
\hline 5 & A04 & $0.009 * * *$ & (19.35) & $0.146^{* * *}$ & $(7.11)$ & $-2.294^{* * *}$ & (22.28) & 0.498 \\
\hline 6 & A05 & $0.009 * * *$ & (20.66) & $0.135^{* * *}$ & $(4.75)$ & 0.230 & $(0.65)$ & 0.101 \\
\hline 7 & B06 & $0.010 * * *$ & (17.58) & 0.027 & (1.17) & $2.850 * * *$ & (27.75) & 0.583 \\
\hline 8 & B07 & $0.009^{* * *}$ & (19.74) & $0.135^{* * *}$ & (5.14) & 0.277 & $(0.92)$ & 0.128 \\
\hline 9 & B08 & $0.015^{* * *}$ & (41.11) & $-0.133^{* * *}$ & $(-8.95)$ & $3.841^{* * *}$ & (36.06) & 0.442 \\
\hline 10 & B09 & $0.010^{* * *}$ & (15.89) & $0.290^{* * *}$ & $(11.50)$ & $-1.766^{* * *}$ & (17.41) & 0.483 \\
\hline 11 & B11 & $0.013^{* * *}$ & (24.06) & $0.265^{* * *}$ & $(7.45)$ & $-2.010^{* * *}$ & $(-4.28)$ & 0.048 \\
\hline 12 & $\mathrm{C} 14$ & $0.017^{* * *}$ & (38.17) & $-0.288^{* * *}$ & $(-13.19)$ & $7.423^{* * *}$ & $(37.20)$ & 0.456 \\
\hline 13 & $\mathrm{C} 15$ & $0.014^{* * *}$ & (50.29) & $0.085^{* * *}$ & $(7.26)$ & $1.605^{* * *}$ & (60.64) & 0.772 \\
\hline 14 & $\mathrm{C} 17$ & $0.016^{* * *}$ & (38.32) & $-0.241^{* * *}$ & $(-9.64)$ & $5.937 * * *$ & (18.97) & 0.220 \\
\hline 15 & C18 & $0.017^{* * *}$ & (36.88) & $-0.346^{* * *}$ & $(-13.27)$ & $-8.768^{* * *}$ & (32.78) & 0.393 \\
\hline 16 & C19 & $0.010^{* * *}$ & (13.17) & $0.132^{* * *}$ & $(4.24)$ & $2.445^{* * *}$ & (21.73) & 0.479 \\
\hline 17 & $\mathrm{C} 20$ & $0.008^{* * *}$ & (18.64) & $0.240^{* * *}$ & (15.52) & $0.580^{* * *}$ & (16.69) & 0.400 \\
\hline 18 & $\mathrm{C} 21$ & $0.015^{* * *}$ & (28.16) & $-0.267^{* * *}$ & $(-9.97)$ & $7.089^{* * *}$ & (31.99) & 0.480 \\
\hline 19 & $\mathrm{C} 22$ & $0.014^{* * *}$ & (37.79) & 0.026 * & $(1.80)$ & $-2.708^{* * *}$ & (41.56) & 0.562 \\
\hline 20 & $\mathrm{C} 23$ & $0.009^{* * *}$ & (20.55) & $0.242^{* * *}$ & (14.25) & $0.872^{* * *}$ & (18.47) & 0.401 \\
\hline 21 & $\mathrm{C} 24$ & $0.012^{* * *}$ & (27.95) & -0.025 & $(-1.49)$ & $2.415^{* * *}$ & (28.15) & 0.362 \\
\hline 22 & $\mathrm{C} 25$ & $0.011^{* * *}$ & (23.42) & $0.203^{* * *}$ & $(6.53)$ & $-1.012^{* *}$ & $(-2.50)$ & 0.079 \\
\hline 23 & $\mathrm{C} 26$ & $0.012^{* * *}$ & (27.52) & $0.228^{* * *}$ & (8.48) & $-1.950 * * *$ & $(-5.50)$ & 0.083 \\
\hline 24 & $\mathrm{C} 27$ & $0.016^{* * *}$ & (57.70) & $-0.169^{* * *}$ & $(-15.23)$ & $4.517^{* * *}$ & (57.08) & 0.648 \\
\hline 25 & $\mathrm{C} 28$ & $0.013^{* * *}$ & (35.34) & $0.035^{* * *}$ & $(2.60)$ & $1.768^{* * *}$ & (28.25) & 0.404 \\
\hline 26 & $\mathrm{C} 29$ & $0.016^{* * *}$ & (30.98) & $-0.201^{* * *}$ & $(-6.22)$ & $-5.631^{* * *}$ & (13.92) & 0.160 \\
\hline 27 & C30 & $0.013^{* * *}$ & (26.21) & $0.173^{* * *}$ & $(5.33)$ & -0.262 & $(-0.62)$ & 0.074 \\
\hline 28 & C31 & $0.012^{* * *}$ & (42.43) & $-0.054^{* * *}$ & $(-4.68)$ & $2.733^{* * *}$ & (48.69) & 0.599 \\
\hline 29 & C32 & $0.017^{* * *}$ & (37.33) & $-0.364^{* * *}$ & $(-14.36)$ & $-6.702^{* * *}$ & (23.14) & 0.231 \\
\hline 30 & C33 & $0.016^{* * *}$ & (45.67) & $-0.229^{* * *}$ & $(-14.99)$ & $4.988^{* * *}$ & (37.94) & 0.445 \\
\hline 31 & C34 & $0.015^{* * *}$ & (31.98) & $-0.048 *$ & $(-1.70)$ & $2.687^{* * *}$ & $(7.53)$ & 0.101 \\
\hline 32 & C35 & $0.013^{* * *}$ & (24.94) & $0.238^{* * *}$ & $(7.44)$ & $-1.675^{* * *}$ & $(-3.93)$ & 0.074 \\
\hline 33 & C36 & $0.017^{* * *}$ & (43.78) & $-0.336^{* * *}$ & $(-16.74)$ & $6.796^{* * *}$ & (31.09) & 0.353 \\
\hline 34 & $\mathrm{C} 37$ & $0.013^{* * *}$ & (24.17) & $0.145^{* * *}$ & $(4.22)$ & $0.892 * *$ & $(2.02)$ & 0.098 \\
\hline 35 & C 38 & $0.016^{* * *}$ & $(9.08)$ & -0.065 & $(-0.78)$ & 1.643 & (1.34) & 0.120 \\
\hline 36 & C39 & $0.015^{* * *}$ & (9.63) & -0.016 & $(-0.23)$ & 0.795 & $(0.83)$ & 0.093 \\
\hline 37 & $\mathrm{C} 40$ & $0.005^{* * *}$ & $(2.80)$ & $0.385^{* * *}$ & $(3.56)$ & $-3.662 * * *$ & $(-2.88)$ & 0.115 \\
\hline 38 & C41 & $0.012^{* * *}$ & $(8.48)$ & $-0.132 * *$ & $(-2.41)$ & $3.585^{* * *}$ & (14.31) & 0.734 \\
\hline 39 & D44 & $0.009^{* * *}$ & (23.58) & $0.277^{* * *}$ & $(11.66)$ & $-1.954^{* * *}$ & $(-6.31)$ & 0.150 \\
\hline
\end{tabular}


Table 6. Cont.

\begin{tabular}{|c|c|c|c|c|c|c|c|c|}
\hline 40 & D45 & $0.012^{* * *}$ & (27.78) & $-0.234^{* * *}$ & $(-10.49)$ & $5.519 * * *$ & (29.77) & 0.380 \\
\hline 41 & E47 & $0.011^{* * *}$ & (25.96) & $-0.086^{* * *}$ & $(-4.64)$ & $-3.734^{* * * *}$ & (29.33) & 0.379 \\
\hline 42 & $\mathrm{E} 48$ & $0.018^{* * *}$ & (41.11) & $-0.343^{* * *}$ & $(-15.49)$ & $7.722^{* * *}$ & (35.95) & 0.420 \\
\hline 43 & E50 & $0.011^{* * *}$ & (22.07) & $0.059 * * *$ & $(2.69)$ & $3.498^{* * *}$ & (29.80) & 0.511 \\
\hline 44 & F51 & $0.011^{* * *}$ & (25.41) & $0.172 * * *$ & (6.33) & $-0.717^{* *}$ & $(-2.02)$ & 0.112 \\
\hline 45 & F52 & $0.009^{* * *}$ & (22.78) & $0.295^{* * *}$ & (10.41) & $-1.831^{* * *}$ & $(-4.77)$ & 0.145 \\
\hline 46 & G54 & $0.012^{* * *}$ & (31.35) & $-0.210^{* * *}$ & $(-9.14)$ & $5.300 * * *$ & $(20.95)$ & 0.262 \\
\hline 47 & G55 & $0.015^{* * *}$ & (32.84) & $-0.340^{* * *}$ & $(-13.52)$ & $7.214^{* * *}$ & $(28.44)$ & 0.329 \\
\hline 48 & G56 & $0.003^{* * *}$ & $(9.47)$ & $0.402^{* * *}$ & $(16.24)$ & $-3.627^{* * *}$ & $(-11.78)$ & 0.142 \\
\hline 49 & G58 & $0.009^{* * *}$ & (20.42) & $0.099 * * *$ & $(5.15)$ & $2.301^{* * *}$ & $(27.36)$ & 0.515 \\
\hline 50 & G59 & $0.014^{* * *}$ & (26.77) & $-0.279^{* * *}$ & $(-10.23)$ & $8.040^{* * *}$ & (41.49) & 0.702 \\
\hline 51 & H61 & $0.009 * * *$ & (20.28) & $0.122 * * *$ & $(4.39)$ & 0.056 & $(0.17)$ & 0.117 \\
\hline 52 & H62 & $0.009^{* * *}$ & (21.74) & $0.038^{* *}$ & $(2.48)$ & $-1.786^{* * *}$ & (35.00) & 0.533 \\
\hline 53 & I63 & $0.017^{* * *}$ & (29.84) & $-0.160^{* * *}$ & $(-5.32)$ & $5.971^{* * *}$ & (20.80) & 0.268 \\
\hline 54 & $\mathrm{I} 64$ & $0.017^{* * *}$ & (27.86) & $-0.302^{* * *}$ & $(-8.57)$ & $-8.097^{* * *}$ & (19.40) & 0.277 \\
\hline 55 & I65 & $0.016^{* * *}$ & (32.24) & $-0.159^{* * *}$ & $(-5.34)$ & $4.849^{* * *}$ & (13.62) & 0.159 \\
\hline 56 & J66 & $0.006^{* * *}$ & (14.54) & $0.069^{* * *}$ & $(3.78)$ & $-2.773^{* * *}$ & (25.33) & 0.468 \\
\hline 57 & $\mathrm{~J} 67$ & $0.008^{* * *}$ & (17.71) & 0.013 & $(0.44)$ & $1.683^{* * *}$ & $(4.85)$ & 0.086 \\
\hline 58 & K70 & $0.008^{* * *}$ & (22.90) & $0.230 * * *$ & (12.03) & $-1.877^{* * *}$ & $(-7.54)$ & 0.231 \\
\hline 59 & L72 & $0.012^{* * *}$ & (23.34) & $0.195^{* * *}$ & (5.55) & 0.220 & $(0.48)$ & 0.093 \\
\hline 60 & M73 & $0.009^{* * *}$ & (11.10) & -0.031 & $(-0.86)$ & $3.165^{* * *}$ & (17.90) & 0.553 \\
\hline 61 & M74 & $0.014^{* * *}$ & (27.28) & $-0.166^{* * *}$ & $(-7.08)$ & $5.986^{* * *}$ & (32.69) & 0.458 \\
\hline 62 & N77 & $0.007^{* * *}$ & (11.05) & $0.370 * * *$ & (14.80) & $0.428^{* * *}$ & $(5.72)$ & 0.332 \\
\hline 63 & Q83 & $0.009^{* * *}$ & (16.25) & $0.089^{* * *}$ & $(4.55)$ & $1.820^{* * *}$ & (32.97) & 0.730 \\
\hline 64 & R85 & $0.012 * * *$ & (19.27) & $-0.048 *$ & $(-1.96)$ & $2.732 * * *$ & (24.70) & 0.472 \\
\hline 65 & R86 & $0.006^{* * *}$ & $(7.92)$ & $0.484^{* * *}$ & (19.38) & $-0.284^{* * *}$ & $(-5.14)$ & 0.279 \\
\hline 66 & R87 & $0.006^{* * *}$ & $(4.56)$ & $0.165^{* * *}$ & $(2.88)$ & $1.690^{* * *}$ & $(9.42)$ & 0.803 \\
\hline 67 & S90 & $0.008^{* * *}$ & (20.87) & $0.036^{* *}$ & $(2.42)$ & $2.183^{* * *}$ & (30.38) & 0.456 \\
\hline
\end{tabular}

Note: $* * * * * * *$ denote test statistics significant at $10 \%, 5 \%$, and $1 \%$ respectively, while $\mathrm{p}$-value in parenthesis.

\subsection{Firm-Level Herding Bias}

\subsubsection{IHR Bias}

Table 7 reports the dummies oftheIHR index among 667 and 379 traded firms of SSE and SZSE, respectively, and favors the hypothesis $2[28,38,56]$. The proportion of holding IHR, dummy 1 , among traded firms varies with respect to time and more variation in IHR seems at SZSE, i.e., minimum $7 \%$ to maximum $13 \%$ during the sample periods.

Table 7. Investors Herding (IHR) index at the SSE and SZSE (2008-2017).

\begin{tabular}{ccccc}
\hline \multirow{2}{*}{ Year } & \multicolumn{2}{c}{ SSE } & \multicolumn{2}{c}{ SZSE } \\
\cline { 2 - 5 } & \multicolumn{2}{c}{ Total of 6 64 A-shares } & \multicolumn{2}{c}{ Total of 379 A-shares } \\
\cline { 2 - 5 } & $\mathbf{1}$ & $\mathbf{0}$ & $\mathbf{1}$ & $\mathbf{0}$ \\
\hline 2008 & 56 & 608 & 51 & 328 \\
2009 & 63 & 601 & 39 & 340 \\
2010 & 66 & 598 & 25 & 354 \\
2011 & 62 & 602 & 46 & 333 \\
2012 & 60 & 604 & 49 & 330 \\
2013 & 56 & 608 & 47 & 332 \\
2014 & 59 & 605 & 45 & 334 \\
2015 & 64 & 600 & 47 & 332 \\
2016 & 63 & 601 & 32 & 347 \\
2017 & 58 & 606 & 58 & 339 \\
\hline
\end{tabular}

Source: Authors' own research, 2019. 


\subsubsection{MHR Bias}

Table 8 demonstrates that the managers of A-shares listed firms at the SZSE appear more likely to follow their peers in their investment decisions. The average proportion of existence MHR, dummy 1 , is $34 \%$ and $35 \%$, varies from $31 \%$ to $38 \%$ and $31 \%$ to $39 \%$ at the SSE and SZSE, respectively. Minimum ratio of holding MHR appears in 2008 and 2010, while the maximum evidence of MHR looks at 2016 and 2012 at the SSE and SZSE, respectively. Table 8 provides a snapshot of IHR and MHR indices among listed firms of the SSE and SZSE for the said sample period.

Table 8. Managers herding (MHR) Index at the SSE and SZSE (2008-2017).

\begin{tabular}{ccccc}
\hline \multirow{2}{*}{ Year } & \multicolumn{2}{c}{ (SSE) } & \multicolumn{2}{c}{ (SZSE) } \\
\cline { 2 - 5 } & Total of $\mathbf{6 6 4}$ A-shares & \multicolumn{1}{c}{ Total of 379 A-shares } \\
\cline { 2 - 5 } & $\mathbf{1}$ & $\mathbf{0}$ & $\mathbf{1}$ & $\mathbf{0}$ \\
\hline 2008 & 209 & 455 & 135 & 244 \\
2009 & 230 & 434 & 143 & 236 \\
2010 & 229 & 435 & 118 & 261 \\
2011 & 218 & 446 & 135 & 244 \\
2012 & 235 & 429 & 146 & 233 \\
2013 & 210 & 454 & 135 & 244 \\
2014 & 230 & 434 & 140 & 239 \\
2015 & 234 & 430 & 130 & 249 \\
2016 & 242 & 422 & 124 & 255 \\
2017 & 220 & 444 & 122 & 257 \\
\hline
\end{tabular}

Bars in Figure 1 explain the increase, decrease and non-monotonic relation between IHR and MHR. At the SSE, both the IHR and MHR both increase in 2008, 2014 and 2015, decreases in 2011, 2013 and 2017. Likewise, both the IHR and MHR at the SZSE both increase in 2008, 2011 2012, and decrease in 2010, 2013 and 2016, the rest of the years show a different trend between IHR and MHR.

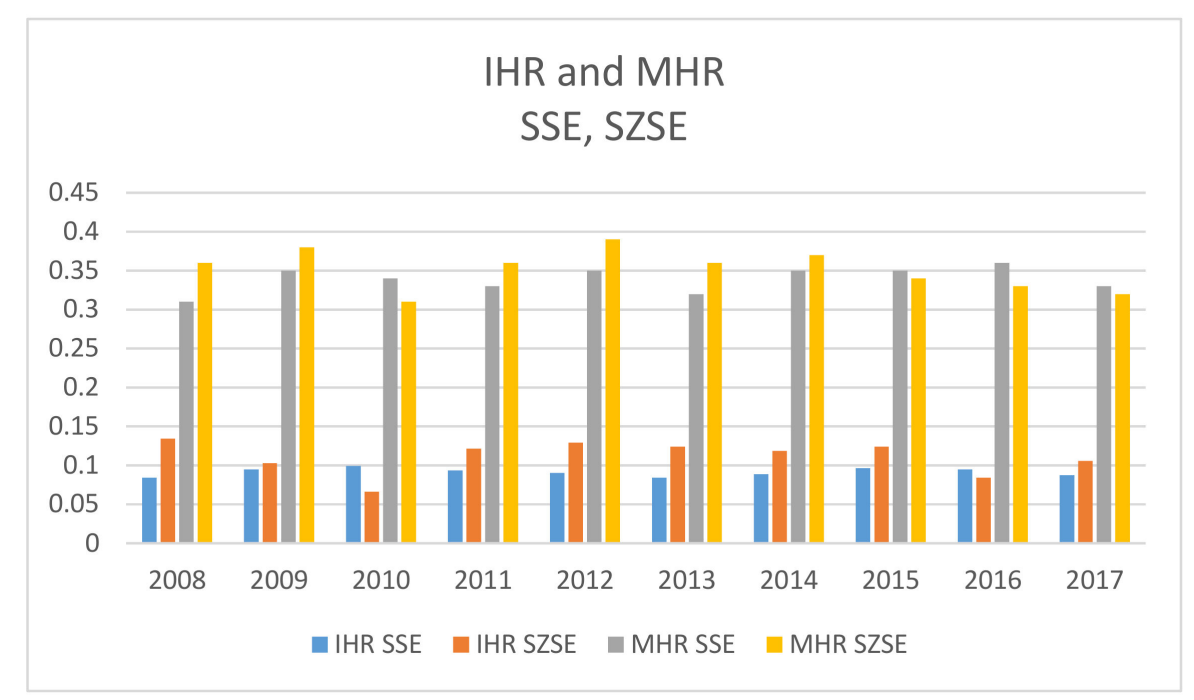

Figure 1. IHR and MHR percentages associated with listed firms of 664-SSE and 379-SZSE. Source: Authors' own research, 2019.

Figure 2 explains the versatile trading behavior of Chinese investors during the sample periods. In this figure, the period of 2013 to 2017 seems to be a highly volatile period of both of the markets where the trading index has divergent experiences. 


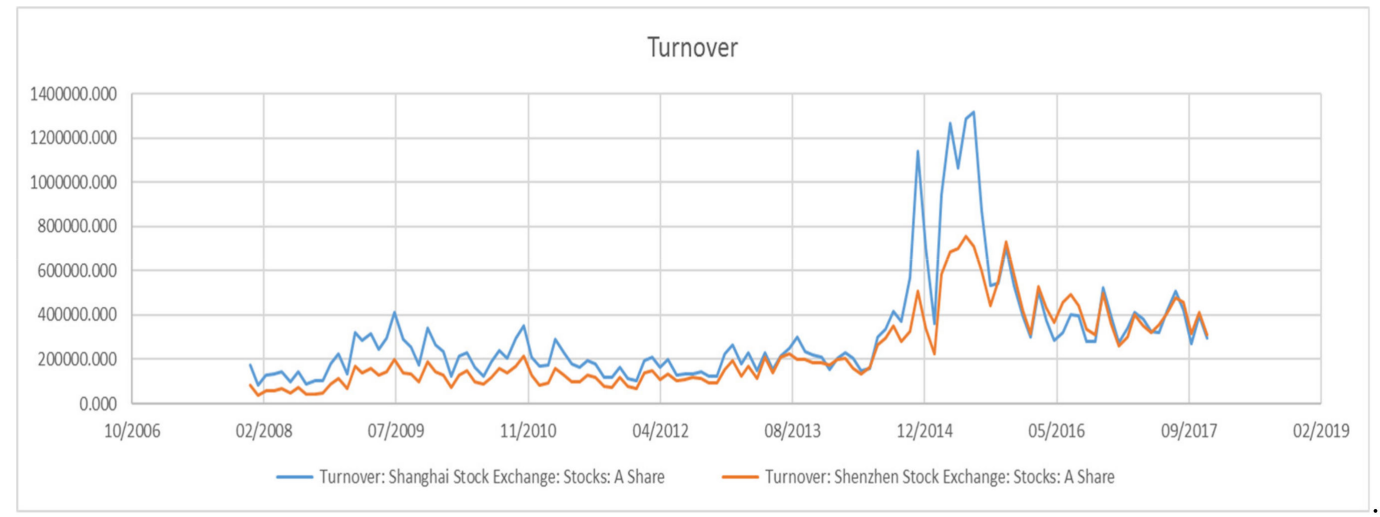

Figure 2. Turnover of A-Shares at SSE and SZSE: Source; CEIC Data. Source: Authors' own research, 2019.

\subsection{Herding Bias and Firm Value}

Impact of IHR and MHR on FV is analyzed through multivariate regression with respect to hypotheses 3 to 5. In Table 9, Table 10, Table 11, Table 12, we use the market to book value as the proxy of FV, which is explained in Table 1.The Hausman test guides us to use the fixed effect regression analysis, which assumes a rejection of the random effect hypothesis under a significant p-value. Hence, we reject the null hypothesis, the random effect is appropriate. Using the following Equations (11)-(13), fixed-effect regression analysis with industries and time dummies reports result in Table 9, Table 10, Table 11, Table 12.

$$
\begin{gathered}
\mathrm{FV}_{\mathrm{t}}=\beta_{0}+\beta_{1} \mathrm{IHR}_{\mathrm{t}}+\beta_{2} \mathrm{CF}_{\mathrm{t}}+\beta_{3} \mathrm{FS}_{\mathrm{t}}+\beta_{4} \mathrm{FL}_{\mathrm{t}}+\beta_{5} \mathrm{FG}_{\mathrm{t}}+\gamma+\mu+\epsilon \\
\mathrm{FV}_{\mathrm{t}}=\beta_{0}+\beta_{1} \mathrm{MHR}_{\mathrm{t}}+\beta_{2} \mathrm{CF}_{\mathrm{t}}+\beta_{3} \mathrm{FS}_{\mathrm{t}}+\beta_{4} \mathrm{FL}_{\mathrm{t}}+\beta_{5} \mathrm{FG}_{\mathrm{t}}+\gamma+\mu+\epsilon \\
\mathrm{FV}_{\mathrm{t}}=\beta_{0}+\beta_{1} \mathrm{IHR}_{\mathrm{t}}+\beta_{2} \mathrm{MHR}_{\mathrm{t}}+\beta_{3} \mathrm{IHR}_{\mathrm{t}} * \mathrm{MHR}_{\mathrm{t}}+\beta_{4} \mathrm{CF}_{\mathrm{t}}+\beta_{5} \mathrm{FS}_{\mathrm{t}}+\beta_{6} \mathrm{FL}_{\mathrm{t}}+\beta_{7} \mathrm{FG}_{\mathrm{t}}+\gamma+\mu+\epsilon
\end{gathered}
$$

Table 9, a fixed effect regression model with year and industry dummies illustrates the impact of IHR, MHR and their interaction (IHR*MHR) on FV at the listed firms of the SSE and SZSE under the full sample period. The results support the third hypothesis in both of the markets, which implies that IHR positively drives the FV ceteris paribus. Whereas, the fourth and fifth hypotheses based on MHR hold true at the SZSE, where MHR and interaction demonstrate the positive impact on the FV. Overall findings document the influence of herding bias upon the FV, which gains support by prior literature $[6,12,22]$. However, the strength of relation exists insignificant during the sample period. To further diagnose the intensity of the said relation, we revisit the sample and select the extreme trading period of A-shares in line with the related literature [16,28], based upon the turnover of shares at the SSE and the SZSE. Table 10 presents the result of IHR, MHR and their interaction on the FV from 2013 to 2017, a highly divergent period, shown in Figure 2 of A-shares trading at the SSE and SZSE.

The results in Table 10 reveal that herding bias derives the FV at the SSE and SZSE. It explains that FV at the SSE is adversely affected by the MHR at the 5\% level of significance with $\mathrm{t}$-value (2.03). Whereas, at the SZSE, herding bias positively derives the FV, and this impact seems to be more profound by the IHR, i.e., $10 \%$ significance with a t-value (1.68). Further, CF significantly increases among those firms that are positively influenced by the interaction of IHR and MHR, while FG is positively and significantly caused by negative interaction of herding biases. On the other hand, FS shows the negative and significant impact on the FV regardless of the magnitude of interaction. FL explains the positive impact on FV among the listed firms of both the markets. Results of control variables are consistent with prior literature $[57,58]$. The results support the third and fifth hypotheses of the study only at the SZSE, and contradict all hypotheses at the SSE. The reason for controverting findings from the prior literature, specifically at the SSE, might be due to the high and sharp shift in trading behavior from boom to slump. To capture the impact of this relation at a specific time interval, 
we divide the subsample into annual and bi-annual periods, based on a sharp, shifty, yearly edge turnover of A-shares.

Table 9. MHR, and firm value (FV) (2008-2017).

\begin{tabular}{|c|c|c|c|c|c|c|}
\hline \multirow{3}{*}{ VARIABLES } & \multicolumn{3}{|c|}{ SSE } & \multicolumn{3}{|c|}{ SZSE } \\
\hline & (1) & (2) & (3) & (4) & (5) & (6) \\
\hline & MB & MB & MB & MB & MB & MB \\
\hline IHR & $\begin{array}{l}0.033 \\
(0.49)\end{array}$ & & & $\begin{array}{l}0.072 \\
(0.86)\end{array}$ & & \\
\hline MHR & & $\begin{array}{l}-0.063 \\
(-1.52)\end{array}$ & & & $\begin{array}{l}0.032 \\
(0.57)\end{array}$ & \\
\hline $\mathrm{IHR}^{*} \mathrm{MHR}$ & & & $\begin{array}{l}-0.166 \\
(-1.19)\end{array}$ & & & $\begin{array}{l}0.059 \\
(0.33)\end{array}$ \\
\hline $\mathrm{CF}$ & $\begin{array}{c}0.459 * * \\
(2.26)\end{array}$ & $\begin{array}{c}0.459 * * \\
(2.26)\end{array}$ & $\begin{array}{c}0.463^{* *} \\
(2.28)\end{array}$ & $\begin{array}{c}1.362 * * * \\
(5.03)\end{array}$ & $\begin{array}{c}1.355^{* * *} \\
(5.01)\end{array}$ & $\begin{array}{c}1.359 * * * \\
(5.02)\end{array}$ \\
\hline FL & $\begin{array}{c}-0.030 * * * \\
(-2.59)\end{array}$ & $\begin{array}{c}-0.030 * * \\
(-2.55)\end{array}$ & $\begin{array}{c}-0.030^{* *} \\
(-2.54)\end{array}$ & $\begin{array}{c}-0.036 \text { * } \\
(-1.94)\end{array}$ & $\begin{array}{c}-0.036 \text { * } \\
(-1.93)\end{array}$ & $\begin{array}{c}-0.037 \text { * } \\
(-1.95)\end{array}$ \\
\hline FG & $\begin{array}{c}-0.035^{*} \\
(-1.88)\end{array}$ & $\begin{array}{c}-0.034 \text { * } \\
(-1.82)\end{array}$ & $\begin{array}{c}-0.034 \text { * } \\
(-1.82)\end{array}$ & $\begin{array}{l}0.031 \\
(1.16)\end{array}$ & $\begin{array}{l}0.031 \\
(1.16)\end{array}$ & $\begin{array}{l}0.031 \\
(1.15)\end{array}$ \\
\hline FS & $\begin{array}{c}-0.672 * * * \\
(-30.44)\end{array}$ & $\begin{array}{c}-0.672^{* * *} \\
(-30.41)\end{array}$ & $\begin{array}{c}-0.672 * * * \\
(-30.42)\end{array}$ & $\begin{array}{c}-0.708^{* * *} \\
(-23.81)\end{array}$ & $\begin{array}{c}-0.709^{* * *} \\
(-23.80)\end{array}$ & $\begin{array}{c}-0.709 * * * \\
(-23.81)\end{array}$ \\
\hline Constant & $\begin{array}{c}17.185^{* * *} \\
(42.83)\end{array}$ & $\begin{array}{c}17.172 * * * \\
(42.80)\end{array}$ & $\begin{array}{c}17.162^{* * *} \\
(42.76)\end{array}$ & $\begin{array}{c}17.063^{* * *} \\
(28.15)\end{array}$ & $\begin{array}{c}17.062 * * * \\
(28.14)\end{array}$ & $\begin{array}{c}17.071^{* * *} \\
(28.14)\end{array}$ \\
\hline Observations & 6640 & 6640 & 6640 & 3790 & 3790 & 3790 \\
\hline R-squared & 0.354 & 0.355 & 0.355 & 0.329 & 0.329 & 0.330 \\
\hline Adj. $R^{2}$ & 0.346 & 0.347 & 0.347 & 0.318 & 0.318 & 0.318 \\
\hline F-Stat & 43.91 & 43.95 & 42.92 & 29.05 & 29.04 & 28.15 \\
\hline Year Effect & Yes & Yes & Yes & Yes & Yes & Yes \\
\hline Ind. Effect & Yes & Yes & Yes & Yes & Yes & Yes \\
\hline
\end{tabular}

Note: $* * * * * * *$ denote test statistics significant at $10 \%, 5 \%$, and $1 \%$, respectively,while the $p$-value is in parentheses. Where $\mathrm{MB}=\mathrm{FV}$ measured market to book value of assets, IHR = investor herding, MHR = managers herding, $\mathrm{CF}=$ cash flow, $\mathrm{FL}=$ firm leverage, $\mathrm{FG}=$ firm growth, $\mathrm{FS}=$ firm size.Source: Authors' own research, 2019.

Table 10. MHR, and FV (2013-2017).

\begin{tabular}{|c|c|c|c|c|c|c|}
\hline \multirow{3}{*}{ VARIABLES } & \multicolumn{3}{|c|}{ SSE } & \multicolumn{3}{|c|}{ SZSE } \\
\hline & (1) & (2) & (3) & (4) & (5) & (6) \\
\hline & MB & MB & MB & MB & MB & MB \\
\hline IHR & $\begin{array}{l}-0.028 \\
(-0.16)\end{array}$ & & & $\begin{array}{c}0.127^{*} \\
(1.68)\end{array}$ & & \\
\hline MHR & & $\begin{array}{c}-0.218 \text { ** } \\
(-2.03)\end{array}$ & & & $\begin{array}{l}-0.059 \\
(-0.65)\end{array}$ & \\
\hline $\mathrm{IHR}^{*} \mathrm{MHR}$ & & & $\begin{array}{l}-0.196 \\
(-0.53)\end{array}$ & & & $\begin{array}{l}0.136 \\
(0.46)\end{array}$ \\
\hline $\mathrm{CF}$ & $\begin{array}{l}0.516 \\
(0.98)\end{array}$ & $\begin{array}{l}0.526 \\
(1.00)\end{array}$ & $\begin{array}{l}0.528 \\
(1.01)\end{array}$ & $\begin{array}{c}1.160^{* * *} \\
(2.69)\end{array}$ & $\begin{array}{c}1.161^{* * *} \\
(2.69)\end{array}$ & $\begin{array}{c}1.177^{* * *} \\
(2.72)\end{array}$ \\
\hline FL & $\begin{array}{l}0.042 \\
(1.40)\end{array}$ & $\begin{array}{l}0.045 \\
(1.48)\end{array}$ & $\begin{array}{l}0.045 \\
(1.50)\end{array}$ & $\begin{array}{l}0.028 \\
(0.92)\end{array}$ & $\begin{array}{l}0.028 \\
(0.92)\end{array}$ & $\begin{array}{l}0.027 \\
(0.91)\end{array}$ \\
\hline FG & $\begin{array}{c}0.089 * \\
(1.81)\end{array}$ & $\begin{array}{l}0.092 * \\
(1.88)\end{array}$ & $\begin{array}{l}0.093^{*} \\
(1.89)\end{array}$ & $\begin{array}{l}-0.023 \\
(-0.52)\end{array}$ & $\begin{array}{l}-0.020 \\
(-0.47)\end{array}$ & $\begin{array}{l}-0.022 \\
(-0.50)\end{array}$ \\
\hline FS & $\begin{array}{c}-0.965^{* * *} \\
(-16.68)\end{array}$ & $\begin{array}{c}-0.963 \text { *** } \\
(-16.66)\end{array}$ & $\begin{array}{c}-0.964^{* * *} \\
(-16.66)\end{array}$ & $\begin{array}{c}-0.712^{* * *} \\
(-15.12)\end{array}$ & $\begin{array}{c}-0.710^{* * *} \\
(-15.04)\end{array}$ & $\begin{array}{c}-0.711^{* * *} \\
(-15.06)\end{array}$ \\
\hline Constant & $\begin{array}{c}20.731^{* * *} \\
(19.95)\end{array}$ & $\begin{array}{c}20.664^{* * * *} \\
(19.89)\end{array}$ & $\begin{array}{c}20.655^{* * *} \\
(19.87)\end{array}$ & $\begin{array}{c}18.233^{* * *} \\
(19.14)\end{array}$ & $\begin{array}{c}18.158^{* * *} \\
(19.06)\end{array}$ & $\begin{array}{c}18.210 * * * \\
(19.08)\end{array}$ \\
\hline Observations & 3320 & 3320 & 3320 & 1895 & 1895 & 1895 \\
\hline R-squared & 0.200 & 0.201 & 0.201 & 0.323 & 0.323 & 0.323 \\
\hline Adj. $R^{2}$ & 0.181 & 0.182 & 0.181 & 0.302 & 0.301 & 0.301 \\
\hline F-Stat & 10.52 & 10.59 & 10.32 & 15.10 & 15.08 & 14.59 \\
\hline Year Effect & Yes & Yes & Yes & Yes & Yes & Yes \\
\hline Ind. Effect & Yes & Yes & Yes & Yes & Yes & Yes \\
\hline
\end{tabular}

Note: $* * *,+* *$ denote test statistics significant at $10 \%, 5 \%$, and $1 \%$, respectively, while their $p$-value is in parentheses. Where $\mathrm{MB}=\mathrm{FV}$ measured market to book value of assets, IHR = investor herding, $\mathrm{MHR}=$ managers herding, $\mathrm{CF}=$ cash flow, $\mathrm{FL}=$ firm leverage, $\mathrm{FG}=$ firm growth, $\mathrm{FS}=$ firm size.Source: Authors' own research, 2019. 


\subsubsection{IHR, MHR, and FFP During Economic Shocks}

Table 11 reports the impact of IHR and MHR on FV during the economic shocks, as an exogenous factor, we divide the sub-sample into four intervals, i.e., 2013, 2014-2015, 2016, 2017, annually and bi-annually based on the turnover trend shown inFigure 2. Among these four intervals, second interval, 2014-2015, is bi-annual, as this period contains the versatile trading behavior, bottom-peak-bottom, of the index. Thefirst interval 2013 is in a less volatile period of A-shares at both the markets. During this year, IHR negatively influences the FV, while MHR positively influenced the FV at the SSE and SZSE, respectively. The interaction term explains the positive relation with $\mathrm{FV}$, and this relation seems $10 \%$ significant at the SZSE. The second interval 2014-2015 shows the extreme trading behavior of A-shares at both the market where the SSE seems more volatile relative to the SZSE. Over this period, IHR exhibits a positive and significant effect on the FV, while MHR significantly and negatively influences the FV. Apparently, FV at SSE seems to be more sensitive towards the IHR, whereas, at the SZSE, IHR and MHR both significantly drive the FV with a $90 \%$ level of confidence. The interaction term explains that in the extreme trading period, IHR and MHR negatively influenced the FV.

The results in 2016, the immediate year after the highest and the lowest market index in 2015, capture the effects of the aftershocks. Market movement over this year quarterly moves up and down and explains the negative impact of IHR and MHR on the FV at both markets. The interaction term explains the mixed results at both the SSE and SZSE, respectively.

The last interval (2017), is relatively low volatile, compared with second and third interval, which explains the negative and positive impact of IHR and its interaction term on FV at the SSE and SZSE, respectively. However, MHR clarifies a negative and positive impact on FV at the SSE and SZSE.

Theoverall finding over the four intervals demonstrates that IHR and MHR strongly appears, and interactively negatively derives the FV during the extreme market movements. Whereas, in the low volatile period, the significance disappears, and the negative interactive effect on the FV at SSE continues as aftereffects. We also capture the impact of herding bias during the said sample in the group of industries listed at the SSE and SZSE. For this purpose, we rearrange our sample based on the group A-industry classification cited in the CSMAR database. Table 12 describes the results of industries and market wise relation of herding bias with FV.

Table 11. IHR, MHRand FV during economic shocks.

\begin{tabular}{ccccccccc}
\hline & \multicolumn{2}{c}{$\mathbf{2 0 1 3}$} & \multicolumn{2}{c}{$\mathbf{2 0 1 4 - 2 0 1 5}$} & \multicolumn{2}{c}{$\mathbf{2 0 1 6}$} & \multicolumn{2}{c}{$\mathbf{2 0 1 7}$} \\
\cline { 2 - 10 } VARIABLES & $\mathbf{( 1 )}$ & $\mathbf{( 3 )}$ & $\mathbf{( 3 )}$ & $\mathbf{( 3 )}$ & $\mathbf{( 3 )}$ & $\mathbf{( 4 )}$ & $\mathbf{( 5 )}$ & $\mathbf{( 6 )}$ \\
\cline { 2 - 10 } & SSE & SSE & SSE & SZSE & SSE & SZSE & SSE & SZSE \\
\cline { 2 - 9 } & MB & MB & MB & MB & MB & MB & MB & MB \\
\hline IHR & -0.301 & -0.233 & $0.360^{* * *}$ & $0.327 * *$ & -0.159 & -0.198 & -0.097 & 0.344 \\
& $(-1.30)$ & $(-0.90)$ & $(2.78)$ & $(2.41)$ & $(-0.70)$ & $(-0.68)$ & $(-0.44)$ & $(1.24)$ \\
MHR & 0.031 & 0.217 & $-0.143^{*}$ & $-0.201^{* *}$ & -0.048 & -0.074 & 0.142 & 0.269 \\
IHR*MHR & $(0.22)$ & $(1.21)$ & $(-1.73)$ & $(-2.26)$ & $(-0.34)$ & $(-0.42)$ & $(1.07)$ & $(1.46)$ \\
& 0.240 & $0.921^{*}$ & -0.135 & -0.188 & -0.124 & 0.003 & -0.220 & 0.748 \\
Observations & $(0.47)$ & $(1.65)$ & $(-0.49)$ & $(-0.65)$ & $(-0.27)$ & $(0.00)$ & $(-0.41)$ & $(1.21)$ \\
Year Effect & 1707 & 1422 & 1707 & 1422 & 1707 & 1422 & 1707 & 1422 \\
Ind. Effect & Yes & Yes & Yes & Yes & Yes & Yes & Yes & Yes \\
\hline
\end{tabular}

t-statistics in parentheses; ${ }^{* * *} p<0.01,{ }^{* *} p<0.05,{ }^{*} p<0.1$; Source: Authors' own research, 2019.

\subsubsection{Group A-Industry Classification}

Table 12 presents the relation of herding bias on the FV at the SSE and SZSE among six groups of industries (Group A-industry classification). Empirical results show that IHR positively and significantly derives the FV at the SZSE in the industry group. While MHR explains the negative and significant impact on the FV under the same industry head. However, the interaction term of IHR and 
MHR exhibits positive impact on FV at the SSE and SZSE, respectively. Likewise, MHR also has a positive significant effect on FV between the Business and Financial sector at the SZSE. The significant impact of MHR on FV at the SZSE is relatively more pronounced than the SSE. IHR and MHR among other sectors explain the mixed on the FV.

Table 12. Interactive impact of IHR and MHR on FV among Industry Group A.

\begin{tabular}{|c|c|c|c|c|c|c|c|c|c|c|}
\hline \multirow{3}{*}{ Groups } & \multicolumn{3}{|c|}{ SSE } & \multicolumn{3}{|c|}{ SZSE } & \multicolumn{2}{|c|}{ SSE } & \multicolumn{2}{|c|}{ SZSE } \\
\hline & (1) & (2) & (3) & (4) & (5) & (6) & (7) & (8) & (9) & (10) \\
\hline & IHR & MHR & $\begin{array}{l}\text { IHR * } \\
\text { MHR }\end{array}$ & IHR & MHR & $\begin{array}{l}\text { IHR * } \\
\text { MHR }\end{array}$ & Adj. $R^{2}$ & F-Stat & Adj. $\mathbf{R}^{2}$ & F-Stat \\
\hline \multirow{3}{*}{ Comprehensive } & $\begin{array}{l}-0.276 \\
(-0.60)\end{array}$ & & & $\begin{array}{l}-1.148 \\
(-1.59)\end{array}$ & & & 0.388 & 17.98 & 0.615 & 16.67 \\
\hline & & $\begin{array}{l}-0.145 \\
(-0.44)\end{array}$ & & & $\begin{array}{l}-0.152 \\
(-0.25)\end{array}$ & & 0.387 & 17.93 & 0.594 & 15.32 \\
\hline & & & $\begin{array}{l}-1.298 \\
(-1.18)\end{array}$ & & & $\begin{array}{l}0.817 \\
(0.40)\end{array}$ & 0.386 & 13.04 & 0.600 & 11.49 \\
\hline \multirow{3}{*}{ Utilities } & $\begin{array}{l}-0.143 \\
(-0.49)\end{array}$ & & & $\begin{array}{l}-0.704 \\
(-1.37)\end{array}$ & & & 0.294 & 40.39 & 0.222 & 19.48 \\
\hline & & $\begin{array}{l}0.158 \\
(0.95)\end{array}$ & & & $\begin{array}{l}-0.003 \\
(-0.01)\end{array}$ & & 0.295 & 40.58 & 0.212 & 18.99 \\
\hline & & & $\begin{array}{l}-0.597 \\
(-0.98)\end{array}$ & & & $\begin{array}{l}-1.472 \\
(-1.19)\end{array}$ & 0.293 & 29.11 & 0.218 & 16.95 \\
\hline \multirow{3}{*}{ Business } & $\begin{array}{l}0.264 \\
(1.24)\end{array}$ & & & $\begin{array}{l}0.213 \\
(0.43)\end{array}$ & & & 0.391 & 47.06 & 0.008 & 12.06 \\
\hline & & $\begin{array}{l}0.014 \\
(0.11)\end{array}$ & & & $\begin{array}{c}0.512 * \\
(1.95)\end{array}$ & & 0.388 & 46.55 & 0.103 & 11.89 \\
\hline & & & $\begin{array}{l}-0.352 \\
(-0.77)\end{array}$ & & & $\begin{array}{l}0.781 \\
(0.37)\end{array}$ & 0.388 & 33.57 & 0.100 & 11.72 \\
\hline \multirow{3}{*}{ Financial } & $\begin{array}{l}-0.013 \\
(-0.02)\end{array}$ & & & $\begin{array}{l}-1.008 \\
(-0.64)\end{array}$ & & & 0.508 & 10.10 & 0.306 & 12.23 \\
\hline & & $\begin{array}{l}0.828 \\
(1.57)\end{array}$ & & & $\begin{array}{l}1.594^{*} \\
(1.87)\end{array}$ & & 0.538 & 11.22 & 0.479 & 13.56 \\
\hline & & & $\begin{array}{l}-0.157 \\
(-0.12)\end{array}$ & & & $\begin{array}{l}-0.170 \\
(-0.43)\end{array}$ & 0.514 & 7.63 & 0.628 & 14.93 \\
\hline \multirow{3}{*}{ Industry } & $\begin{array}{l}0.030 \\
(0.22)\end{array}$ & & & $\begin{array}{c}0.297 \\
* * \\
(2.27)\end{array}$ & & & 0.258 & 137.16 & 0.260 & 112.18 \\
\hline & & $\begin{array}{c}-0.149 \\
* \\
(-1.79)\end{array}$ & & & $\begin{array}{l}0.023 \\
(0.26)\end{array}$ & & 0.260 & 138.01 & 0.258 & 110.80 \\
\hline & & & $\begin{array}{l}0.128 \\
(0.45) \\
\end{array}$ & & & $\begin{array}{l}0.228 \\
(0.80) \\
\end{array}$ & 0.259 & 98.53 & 0.260 & 80.18 \\
\hline \multirow{3}{*}{ Real estate } & $\begin{array}{l}0.051 \\
(0.23)\end{array}$ & & & $\begin{array}{l}-0.034 \\
(-0.06)\end{array}$ & & & 0.331 & 35.53 & 0.321 & 16.59 \\
\hline & & $\begin{array}{l}-0.004 \\
(-0.04)\end{array}$ & & & $\begin{array}{l}-0.125 \\
(-0.33)\end{array}$ & & 0.331 & 35.52 & 0.323 & 16.62 \\
\hline & & & $\begin{array}{l}-0.517 \\
(-1.07)\end{array}$ & & & $\begin{array}{l}1.899 \\
(1.63)\end{array}$ & 0.329 & 25.48 & 0.331 & 15.16 \\
\hline
\end{tabular}

t-statistics in parentheses ${ }^{* * *} p<0.01,{ }^{* *} p<0.05,{ }^{*} p<0.1$; Source: Authors' own research, 2019.

\section{Conclusions}

The literature on herding biases is confined to detection at the aggregate firms, sector/industry, and market level. The study adds to the behavioral finance literature by addressing the surprisingly unnoticed phenomena of the behavioral impact of herding bias on FV at the firm level, using the sample of 1,043 A-Shares listed firms at the SSE and SZSE under fixed effect specification. Initially, we detect the existence of IHR and MHR biases at firm-level applying a CSAD model $[15,35]$ and an investment model of firms' investment absolute deviation approach [6,22]. After such detection, we deploy the panel fixed-effect model with industry and years dummies to investigate the effect of: (1) IHR on FV, (2) MHR on FV and (3) interaction of IHR, and MHR on the FV respectively. 
The empirical results document the presence of IHR and MHR bias at market, sector and firm-level in both equity markets, which potentially drive the $\mathrm{FV}$, while the impact is more pronounced during the extreme trading period i.e., 2014 to 2015. The findings are robust under different time intervals and industry classification, and therefore, offers useful policy implications to understand the behavioral dynamics of investors and managers.

Given the vital role of finance in economic sustainability, the study adds invaluable inputs for policy formulation $[59,60]$, specifically, the findings appear to be important for potential investors, as the firm-level financial information is more relevant to their decision, rather relying on an index. Specifically, we infer that the negative interaction of IHR with MHR results in a bullish trend to the stock markets, while the bearish trend is explained by the positive interaction of IHR and MHR. The probability of a market crash may become higher in those circumstances when both negative IHR and MHR interact with each other and cause the FV to decline. Furthermore, this study infersthat at the SSE, if IHR and MHR shift from insignificance to positive significance, it might be the signal of a sudden boom in the market. Whereas, at the SZSE, this suggests that when a positive and significant impact of IHR disappears with the negative impact of MHR, this might be the reason for the sudden decline in trading activity, and vice versa. Thus, the study facilitates to understand the herding biases associated with the investment decisions of investors and managers and their impact on the FV that help corporate stakeholders, financial analysts and stock market regulators to devise their strategic and regulatory policies accordingly.

Author Contributions: S.S.H.S., M.A.K., and J.O. conceived and designed the experiment; S.S.H.S. analyzed the data; N.M., contributed analysis tool, and S.S.H.S., M.A.K., and D.F.M. wrote the paper.

Funding: This research received no external funding.

Conflicts of Interest: The authors declare no conflict of interest.

\section{References}

1. Foucault, T.; Sraer, D.; Thesmar, D.J. Individual investors and volatility. J. Finance 2011, 66, 1369-1406. [CrossRef]

2. Barber, B.M.; Odean, T. Trading is hazardous to your wealth: The common stock investment performance of individual investors. J. Finance 2000, 55, 773-806. [CrossRef]

3. Kumar, S.; Goyal, N. Behavioural biases in investment decision making-a systematic literature review. Qual. Res. Financ. Mark. 2015, 7, 88-108. [CrossRef]

4. Garber, P.M. Famous first bubbles: The fundamentals of early manias; The mit Press: London, UK, 2001.

5. Christie, W.G.; Huang, R.D. Following the pied piper: Do individual returns herd around the market? Financ. Anal. J. 1995, 51, 31-37. [CrossRef]

6. Alabass, H.S.H.H. The Impact Of Corporate Investment Behaviour On The Corporate Performance. Available online: https://www.abacademies.org/articles/the-impact-of-corporate-investment-behaviour-onthe-corporate-performance-evidence-from-an-emerging-market-7800.html (accessed on 20 July 2019).

7. Blasco, N.; Corredor, P.; Ferreruela, S. Herding, Volatility, and Market Stress in the Spanish Stock Market. In Handbook of Investors' Behavior During Financial Crises; Economou, F., Gavriilidis, K., Gregoriuo, N.G., Kallinterakis, V., Eds.; Elsevier: Amsterdam, The Netherlands, 2017; pp. 151-168.

8. Chen, C.D.; Demirer, R. The profitability of herding: Evidence from Taiwan. Manage. Financ. 2018, 44, 919-934. [CrossRef]

9. Bikhchandani, S.; Hirshleifer, D.; Welch, I. A theory of fads, fashion, custom, and cultural change as informational cascades. J. Polit. Econ. 1992, 100, 992-1026. [CrossRef]

10. Krkoska, E.; Schenk-Hoppé, K.R. Herding in Smart-Beta Investment Products. J. Risk Financ. Manage. 2019, 12, 47. [CrossRef]

11. Choi, N.; Sias, R.W. Institutional industry herding. J. Financ. Econ. 2009, 94, 469-491. [CrossRef]

12. Wang, Q.; Zhang, J. Does individual investor trading impact firm valuation? J. Corp. Finan. 2015, 35, 120-135. [CrossRef] 
13. Mobarek, A.; Mollah, S.; Keasey, K. A cross-country analysis of herd behavior in Europe. J. Int. Financ. Mark. I. 2014, 32, 107-127. [CrossRef]

14. Walter, A.; Moritz Weber, F. Herding in the German Mutual Fund Industry. Eur. Financ. Manag. 2006, 12, 375-406. [CrossRef]

15. Chang, E.C.; Cheng, J.W.; Khorana, A. An examination of herd behavior in equity markets: An international perspective. J. Bank. Financ. 2000, 24, 1651-1679. [CrossRef]

16. Chiang, T.C.; Li, J.; Tan, L. Empirical investigation of herding behavior in Chinese stock markets: Evidence from quantile regression analysis. Global Finance J. 2010, 21, 111-124. [CrossRef]

17. Demirer, R.; Zhang, H. Do firm characteristics matter in explaining the herding effect on returns? Rev. Financ. Econ. 2019, 37, 256-271. [CrossRef]

18. Zhang, F.; Li, M.; Zhang, M. Chinese Financial Market Investors Attitudes toward Corporate Social Responsibility: Evidence from Mergers and Acquisitions. Sustainability 2019, 11, 2615. [CrossRef]

19. Demirer, R.; Kutan, A.M. Does herding behavior exist in Chinese stock markets? J. Int. Financ. Mark. I. 2006, 16, 123-142. [CrossRef]

20. Demirer, R.; Gupta, R.; Lv, Z.; Wong, W.-K. Equity Return Dispersion and Stock Market Volatility: Evidence from Multivariate Linear and Nonlinear Causality Tests. Sustainability 2019, 11, 351. [CrossRef]

21. Tan, L.; Chiang, T.C.; Mason, J.R.; Nelling, E. Herding behavior in Chinese stock markets: An examination of A and B shares. Pac.-Basin Financ. J. 2008, 16, 61-77. [CrossRef]

22. Bo, H.; Li, T.; Sun, Y. Board attributes and herding in corporate investment: Evidence from Chinese-listed firms. Eur. J. Finance 2013, 22, 432-462. [CrossRef]

23. Lao, P.; Singh, H. Herding behaviour in the Chinese and Indian stock markets. J. Asian Econ. 2011, 22, 495-506. [CrossRef]

24. Lee, C.C.; Chen, M.P.; Hsieh, K.M. Industry herding and market states: Evidence from Chinese stock markets. Quant. Financ. 2013, 13, 1091-1113. [CrossRef]

25. Yao, J.; Ma, C.; He, W.P. Investor herding behaviour of Chinese stock market. Int. Rev. Econ. Finance. 2014, 29, 12-39. [CrossRef]

26. Cheng, A.W.W.; Chow, N.S.C.; Chui, D.K.H.; Wong, W.K. The Three Musketeers Relationships between Hong Kong, Shanghai and Shenzhen Before and After Shanghai-Hong Kong Stock Connect. Sustainability 2019, 11, 3845. [CrossRef]

27. Cho, C.H.; Yang, L.J.; Chu, Y.P.; Yang, H.Y. Renewable Energy and Renewable R\&D in EU Countries: A Cointegration Analysis. 2013. Available online: http://www.ajsc.leena-luna.co.jp/AJSCPDFs/Vol.2(1) /AJSC2013(2.1-02).pdf (accessed on 20 February 2019).

28. Shah, M.U.D.; Shah, A.; Khan, S.U. Herding behavior in the Pakistan stock exchange: Some new insights. Res. Int. Business Finance 2017, 42, 865-873. [CrossRef]

29. Grinblatt, M.; Titman, S.; Wermers, R. Momentum investment strategies, portfolio performance, and herding: A study of mutual fund behavior. Am. Econ. Rev. 1995, 85, 1088-1105. Available online: https: //www.jstor.org/stable/2950976?seq=1\#page_scan_tab_contents (accessed on 20 July 2019).

30. Welch, I. Herding Among Security Analysts. J. Financ. Econ. 2005, 58, 369-396. [CrossRef]

31. Lakonishok, J.; Schleifer, A.; Vishny, R. Do Institutional Investors Destabilize Share Prices? Evidence on Herding and Feedback Trading; National Bureau of Economic Research Inc.: Cambridge, MA, USA, 1991.

32. Bueno, P.B. Social Risks in Aquaculture; Bondad-Reantaso, M.G., Arthur, J.R., Subasinghe, R.P., Eds.; FAO: Rome, Italy, 2008; pp. 209-228.

33. Chiang, T.C.; Zheng, D. An empirical analysis of herd behavior in global stock markets. J. Bank. Financ. 2010, 34, 1911-1921. [CrossRef]

34. Balcilar, M.; Demirer, R.; Hammoudeh, S. Investor herds and regime-switching: Evidence from Gulf Arab stock markets. J. Int. Financ. Mark. I. 2013, 295-321. [CrossRef]

35. Zheng, D.; Li, H.; Chiang, T.C. Herding within industries: Evidence from Asian stock markets. Int. Rev. Econ. Financ. 2017, 51, 487-509. [CrossRef]

36. Javed, T.; Zafar, N.; Hafeez, B. Herding behavior in Karachi stock exchange. Int. J. Manag. Sci. Bus. Res. 2011, 2, 19-28. [CrossRef]

37. Javaira, Z.; Hassan, A. An examination of herding behavior in Pakistani stock market. Int. J. Emerg. Mark. 2015, 10, 474-490. [CrossRef] 
38. Yousaf, I.; Ali, S.; Shah, S.Z.A. Herding behavior in Ramadan and financial crises: The case of the Pakistani stock market. Financ. Innov. 2018, 4, 1-16. [CrossRef]

39. Munkh-Ulzii, B.; McAleer, M.; Moslehpour, M.; Wong, W.K. Confucius and herding behaviour in the stock markets in China and Taiwan. Sustainability 2018, 10, 4413. [CrossRef]

40. Chong, T.T.L.; Liu, X.; Zhu, C. What explains herd behavior in the Chinese stock market? J. Behav. Finance 2017, 18, 448-456. [CrossRef]

41. Huberman, G. Familiarity Breeds Investment. Rev. Financ. Stud. 2005, 4, 659-680. Available online: https://ideas.repec.org/a/oup/rfinst/v14y2001i3p659-80.html (accessed on 20 July 2019).

42. Ha, T.V. Price limit regulation and herd behavior in the Vietnamese stock market. 2007. Available online: https://www.researchgate.net/profile/Tran_Ha4/publication/242124528_Price_limit_regulation_and_ herd_behavior_in_the_Vietnamese_stock_market/links/5419c8d30cf2218008bfa031.pdf (accessed on 20 July 2019).

43. Fama, E.F.; French, K.R. The cross-section of expected stock returns. J. Finance 1992, 47, 427-465. [CrossRef]

44. Van Nieuwerburgh, S.; Veldkamp, L. Information immobility and the home bias puzzle. J. Finance 2009, 64, 1187-1215. [CrossRef]

45. Sadaf, R.; Oláh, J.; Popp, J.; Máté, D. An investigation of the influence of the worldwide governance and competitiveness on accounting fraud cases: A cross-country perspective. Sustainability 2018, 10, 588. [CrossRef]

46. Gebka, B.; Wohar, M.E. Causality between trading volume and returns: Evidence from quantile regressions. I. R. E. F. 2013, 27, 144-159. [CrossRef]

47. Hilliard, J.; Zhang, H. Size and price-to-book effects: Evidence from the Chinese stock markets. Pac.-Basin Financ. J. 2015, 32, 40-55. [CrossRef]

48. Prendergast, C.; Stole, L. Impetuous youngsters and jaded old-timers: Acquiring a reputation for learning. J. Political Econ. 1996, 104, 1105-1134. Available online: https://www.journals.uchicago.edu/doi/pdfplus/10. 1086/262055 (accessed on 20 July 2019). [CrossRef]

49. Fong, K.; Gallagher, D.R.; Gardner, P.; Swan, P.L. A closer examination of investment manager herding behavior. Sydney, AU. 2004; Unpublished manuscript.

50. Devenow, A.; Welch, I. Rational herding in financial economics. Eur. Econ. Rev. 1996, 40, 603-615. [CrossRef]

51. Malmendier, U.; Tate, G. CEO overconfidence and corporate investment. J. Finance 2005, 60, 2661-2700. [CrossRef]

52. Demsetz, H.; Villalonga, B. Ownership structure and corporate performance. J. Corp. Financ. 2001, 7, $209-233$. [CrossRef]

53. Chung, K.H.; Pruitt, S.W. A Simple Approximation of Tobin's q. Financ. Manage. 1994, 23, 70-74. [CrossRef]

54. Chen, I.J.; Lin, S.H. Will Managerial Optimism Affect the Investment Efficiency of a Firm? Proc. Econ. Financ. 2012, 2, 73-80. [CrossRef]

55. Ahmad, I.; Oláh, J.; Popp, J.; Máté, D. Does business group affiliation matter for superior performance? Evidence from Pakistan. Sustainability 2018, 10, 3060. [CrossRef]

56. Javed, H.; Bagh, T.; Razzaq, S. Herding Effects, Over Confidence, Availability Bias and Representativeness as Behavioral Determinants of Perceived Investment Performance: An Empirical Evidence from Pakistan Stock Exchange (PSX). J. Glob. Econ. 2017, 6, 2. [CrossRef]

57. Fosu, S.; Danso, A.; Ahmad, W.; Coffie, W. Information asymmetry, leverage and firm value: Do crisis and growth matter? I. R. F. A. 2016, 46, 140-150. [CrossRef]

58. Ni, Y.; Huang, P.; Chiang, P.; Liao, Y. Cash flow statements and firm value: Evidence from Taiwan. Q. Rev. Econ. Finance 2019, 71, 280-290. [CrossRef]

59. Khan, M.A.; Kong, D.; Xiang, J.; Zhang, J. Impact of Institutional Quality on Financial Development: Cross-Country Evidence based on Emerging and Growth-Leading Economies. Emerg. Mark. Financ. Trade 2019, 1-17. [CrossRef]

60. Khan, M.A.; Khan, M.A.; Abdulahi, M.E.; Liaqat, I.; Shah, S.S.H. Institutional quality and financial development: The United States perspective. J. Multinatl. Financ. Manag. 2019, 49, 67-80. [CrossRef] 